7. Child Lang. 26 (1999), 577-618. Printed in the United Kingdom

(C) 1999 Cambridge University Press

\title{
The acquisition of past tense morphology in Icelandic and Norwegian children: an experimental study*
}

\author{
HRAFNHILDUR RAGNARSDÓTTIR \\ Iceland University of Education \\ HANNE GRAM SIMONSEN \\ University of Oslo \\ AND \\ KIM PLUNKETT \\ Oxford University \\ (Received 28 fanuary, i 999. Revised I I February, I999)
}

A BSTRACT

Icelandic and Norwegian past tense morphology contain strong patterns of inflection and two weak patterns of inflection. We report the results of an elicitation task that tests Icelandic and Norwegian children's knowledge of the past tense forms of a representative sample of verbs. This cross-sectional study of four-, six- and eight-year-old Icelandic $(n=92)$ and Norwegian $(n=96)$ children systematically manipulates verb characteristics such as type frequency, token frequency and phonological coherence - factors that are generally considered to have an important impact on the acquisition of inflectional morphology in other languages. Our findings confirm that these factors play an important role in the acquisition of Icelandic and Norwegian. In addition, the results indicate that the predominant source of errors in children shifts during the later stages of development from one weak verb class to the other. We conclude that these findings are consistent with the view that exemplar-based learning, whereby patterns of categorization and generalization are driven by similarity to known forms, appropriately characterizes the acquisition of inflectional systems by Icelandic and Norwegian children.

[*] This work was supported by NOS-H, The Icelandic Research Council, The Iceland University of Education Research Centre (Hrafnhildur Ragnarsdóttir), the Oceania Group, Department of Linguistics, University of Oslo (Hanne Gram Simonsen) and the Economic and Social Research Council, UK (Kim Plunkett). We wish to thank Kirsten Meyer Bjerkan, Heiðrún Kristjánsdóttir and Helga Jónsdóttir for assistance in carrying out the testing, and Michael Thomas, Graham Schafer, and Amalia Björnsdóttir for carrying out the statistical analyses. We also thank two anonymous reviewers for their helpful commentaries on this research. Address for correspondence: Hrafnhildur Ragnarsdóttir, Iceland University of Education, Stakkahlíx, I०5 Reykjavík, Iceland. 
INTRODUCTION

The study of children's acquisition of inflectional morphology has played a prominent theoretical role in cognitive psychology and psycholinguistics over the past 40 years (Berko, I958; Ervin \& Miller, I963; Kuczaj, I977; Bybee \& Slobin, I982; Rumelhart \& McClelland, I986; Pinker \& Prince, I988; Pinker, r99ı; Plunkett \& Marchman, г99ı, г993, г996; Marcus, Pinker, Ullman, Hollander, Rosen \& Xu, I992; Pizzuto \& Caselli, I992; Prasada \& Pinker, I993; Bybee, I 995; Marcus, ı 995; Xu \& Pinker, I 995; Marchman, I 997; Plunkett \& Nakisa, ı 997; Orsolini, Fanari \& Bowles, I 998 , Plunkett \& Juola, in press). However, until recently, much of this work was informed by the study of just a single inflectional system, namely the English past tense. It turns out that the English past tense is quite unusual crosslinguistically in that it consists of just a single suffixation process (add $-e d)$ plus a small number of exceptions such as go $\rightarrow$ went, sit $\rightarrow$ sat. The numerically superior suffixation process is highly productive, forming the basis for novel past tense forms and most overgeneralization errors (Marcus et $a l$., I 992). The processes of past tense formation which characterize the exceptions (typically internal vowel change) are more restricted in their productivity, showing limited extension to novel forms and accounting for a small minority of errors (Xu \& Pinker, i 995, Marchman, I 997).

Other languages exhibit a much greater degree of variation in their inflectional systems and these have formed the basis of intensive study in recent years. For example, the Arabic and German plural systems do not possess a dominant inflectional process. Instead, vowel change processes and/or multiple suffixation processes abound. There is no single process of plural formation which characterizes the majority of forms in these languages. Nevertheless, some researchers (e.g. Clahsen, Rothweiler, Woest \& Marcus, I 992; Marcus, Brinkmann, Clahsen, Wiese \& Pinker, I 995) have argued that these languages possess a MINORITY DEFAULT inflectional process (the $-s$ plural in German and the sound plural ${ }^{1}$ in Arabic) which is their main source of productivity. The minority default characterizes the type of overgeneralization error that children make in these languages, and the manner in which speakers inflect novel forms or assimilate new forms to the language.

Symbolic (or generative) accounts of the acquisition of inflectional morphology (Pinker \& Prince, I 988; Marcus et al., I 992) assume a dual-route mechanism for the processing of regular and exceptional words: a rulegoverned process attempts to inflect all words while an associative memory attempts to identify the exceptions to the rule and block its application. For example, on this view, plural formation of 'sheeps' is blocked by the identification of the exceptional plural form 'sheep' in associative memory

[I] Sound plurals (male and female) involve adding a suffix to the noun. 
whereas plural formation of 'boys' is achieved by application of the rule (add $-s$ ) to the word 'boy'. Overregularization errors occur if the blocking process fails, usually as a result of failure to remember the irregular form. The rulegoverned process acts as a default that applies to any word, offering the language user economy in representation (no need to store information about inflected forms that conform to the default) and creativity (the capacity to inflect forms previously not encountered). The acquisition of a mental representation of the default rule triggers the onset of overregularization errors in children and underpins their ability to inflect novel forms in a systematic way (Marcus et al., I 992).

According to the symbolic account, the default rule is insensitive to factors such as type frequency of word class, the phonological content of the form to be inflected, and the token frequency of the word in the language. In other words, the default rule is impervious to the internal structure (phonological or semantic) of the form to be inflected. In contrast, exceptions to the rule show all the characteristics of storage in associative memory: type and token frequency effects and sensitivity to phonological content. The hallmark of the symbolic default rule is its productivity. The default rule can potentially be applied to any word in the language, irrespective of semantic and phonological content or type and token frequency. In contrast, the productivity of exceptions to the rule is limited to the interference effects exhibited by associative memory systems, i.e. only word forms that are similar to exceptional patterns will take on the inflectional characteristics of those patterns (Pinker, I99I). As a result, irregularization errors in which the inflectional characteristics of exceptions leak to other inflectional classes (pick $\rightarrow$ puck) are reported as rare occurrences (Marcus et al., I 992; Xu \& Pinker, I 995$)$.

Exemplar-based approaches to inflectional morphology, including connectionist accounts (Rumelhart \& McClelland, I986; MacWhinney \& Leinbach, I 99 I ; Plunkett \& Marchman, I 99 I, I 993, I 996) and network models (Bybee, I985, I995; Langacker, I987, I988) assume there is no distinction in the manner in which regular and exceptional forms are handled. For example, connectionist accounts of inflectional morphology assume a single-route mechanism for the processing of both regular and exceptional forms. They are processed by the same network of connections which maps an uninflected form of the word to its inflected form. The network's capacity to inflect novel forms is shaped by its experience with the forms on which it has already been trained. By and large, novel forms will be inflected in the same way as the words in the language they most resemble. However, this exemplar-based process of inflectional categorization will be attenuated by factors such as the type frequency of the inflectional category in the language. Novel forms will experience less of a 'pull' to inflectional categories with low type frequencies than to categories with high type frequencies. Likewise, exemplar-based 
accounts of the inflectional errors produced by children assume that errors arise from interference effects within the representational network of words known to the speaker. Words that are similar to many members of another inflectional class are more likely to be erroneously inflected than words that are relatively isolated. Again, these interference effects will be attenuated by factors such as the token frequency of individual words. Words with high token frequencies are less likely to be erroneously inflected than words with a low token frequency (Plunkett \& Marchman, I 99 I; Bybee, I 995).

According to exemplar-based accounts of inflectional morphology, the patterns of generalization and errors observed in speakers of a language emerge from the interactions in the network of representations of the words they have learnt. These patterns will vary from speaker to speaker and language to language. In contrast to the symbolic rule-based account of inflectional morphology, there is no privileged, explicit, default rule. If there is a default in the language, it is assumed to be an emergent property of the particular configuration of words known to the speaker, taking into account such factors as type and token frequency, and phonological similarity. In any case, these same factors are assumed to influence the behaviour of all inflectional types in the language. On this view, the productivity of an inflectional type is a graded affair. Overregularization and irregularization errors are assumed to arise from qualitatively similar interference effects in associative memory. The relatively infrequent occurrence of irregularization errors is assumed to reflect the relative robustness of regular forms (and some irregulars) presumably due to their higher type frequency (or token frequency).

In English, the inflectional systems of the past tense and the plural are highly regular. Irregular past tense forms and irregular noun plurals constitute only $4 \%$ and $2 \%$ of their respective systems (Marcus, I 995). The dual-route account of inflectional morphology is very efficient at representing these systems since only a minority of forms need to be stored in associative memory. The default rule can deal with the rest. An exemplar-based account stores information about all the words. Nevertheless, the dominance of the regular words in the system results in the network producing regular responses to novel words. Consequently, dual-route and exemplar-based approaches can both explain the preponderance of regular responses to novel words by English speakers but for different reasons: the dual-route account exploits a default rule which attempts to regularize any word available to the language user. The exemplar-based account exploits the skewed distribution in favour of regular words in the language.

However, it has been claimed that a speaker's ability to produce a default response to novel words or overgeneralize the default to exceptional words does not rely upon a numerical superiority of the words that epitomize the default in the language. For example, Clahsen et al. ( I 992) and Marcus et al. 
( I 995) claim that the $-s$ plural in German is the default process even though it constitutes a minority of the plural forms in the language. A similar claim is made for the default status of the 'sound' plural in Arabic. These authors claim that languages whose speakers conform to a minority default pattern, appear to present a major challenge to exemplar-based accounts of inflectional morphology since networks operating on the principle of 'respond on the basis of similarity to what you already know' are unlikely to produce a default response to novel forms.

Hare, Elman \& Daugherty (r995) have demonstrated that connectionist models of inflectional morphology can learn a default response even in the absence of superior numbers for the default class. Two factors contribute to a network's capacity to respond in a default-like fashion: first, words that look similar are not always inflected in similar ways (see the discussion of type and token frequency above). Secondly, the phonological distribution of the words in the language influences the ability of the network to act in a default-like fashion. Under appropriate conditions, it is possible for a network to learn a distributional default. Hare et al. (i995) show how a minority default inflection can emerge in a model of Old English.

Plunkett \& Nakisa ( I 997) trained a single-route neural network model and a dual-route model on the Arabic plural and evaluated their performance on words not encountered in the training set. They showed that the network was superior to the dual-route model at predicting the plural class of Arabic words on which it had never been trained. In particular, prediction of membership in the sound plural class was more accurate in the neural network model. In a similar fashion, Nakisa \& Hahn ( I 996) have shown that a connectionist network trained on a subset of German plurals accurately predicts the class membership of German plurals that it has never seen before.

The network model is in much the same position as the Arabic or German child who may have to guess how to form the plural of a word. Interestingly, the Plunkett \& Nakisa (r 997) model predicted that Arabic children will initially overgeneralize the 'sound plural' inflection' to other nouns. However, as training continues and error rate decreases, the 'sound plural' overgeneralizations cease to be the dominant error type and are replaced by 'broken plural' ${ }^{3}$, overgeneralizations. These predictions have been corroborated in a study of the acquisition of plural morphology in Palestinian Arabic

[2] More precisely, the female 'sound plural' inflection.

[3] Broken plural inflections involve changes to the stem of the noun. There are roughly 77 types of 'broken plural' which vary widely in type frequency. 'Broken plural' overgeneralizations predicted by the Plunkett \& Nakisa (1997) model are dominated by the three 'broken plural' classes with the highest type frequency. Together, the 77 'broken plural' classes make up about $80 \%$ of the plural system. The 'sound plural' (male and female) constitutes the remaining $20 \%$. 
(Ravid \& Farrah, I997). When Palestinian Arabic children start systematically inflecting noun plurals (between the ages of three and four), they initially overgeneralize 'sound plural' to other inflectional classes. Subsequently, these 'sound plural' overgeneralizations almost disappear to be replaced by 'broken plural' overgeneralizations.

This shift from one predominant type of overgeneralization to another is difficult to explain from the dual-route, symbolic approach to inflectional morphology, as it appears to manifest a developmental shift from a default rule-governed process of overgeneralization to an exemplar-based process of overgeneralization. ${ }^{4}$ If the default rule remained in the child's representational system, one would expect it to remain a significant source of productivity as reflected in the type of overgeneralization errors observed, which does not seem to be the case. Furthermore, Plunkett \& Nakisa ( I 997) argued that, for the network model at least, generalization of the 'sound plural' inflection to other nouns is best predicted by the similarity of the target noun to other 'sound plurals' in the language. This result suggests that postulating a default rule in Arabic is redundant.

How might an exemplar-based approach explain the observed shift from 'sound plural' based overgeneralizations to 'broken plural' based overgeneralizations? In the network model, it is quite easy to see why this happens: although 'sound plurals' constitute a minority of the forms in the plural system as a whole, they nevertheless constitute the largest single class in the system (about $20 \%$ of the forms). Early on, this type frequency factor dominates learning and provides the main source of productivity. However, as the system learns an increasing number of 'broken plurals' and 'sound plurals' it is able to identify more reliable phonological cues to plural class membership and plural classification improves. It turns out that some of the 'broken plural' classes are more widely distributed in phonological space than the 'sound plural' (see Plunkett \& Nakisa, I 997). Hence, some 'broken plural' inflections trump the 'sound plural' in the productivity stakes. The shift in type of overgeneralization will increase as the child learns more 'broken plurals'.

Recently, Orsolini et al. ( I998) have argued that Italian children do not exploit a default inflectional pattern in their language. Rather, different inflectional types show graded levels of productivity. Furthermore, the productivity of inflectional types is influenced by type and token frequency effects as well as by phonological similarity. The study also reports shifting patterns of overgeneralization at different ages (five-years-old to eight-yearsold) in these Italian children.

[4] Broken plural classes are characterized by strict phonological templates. The broken plural overgeneralization errors produced by Palestinian Arabic children reflect the similarity of the incorrectly inflected nouns to these broken plural types. 
Taken together, these results suggest that the process by which inflectional classes are acquired by children need not involve the mental representation of symbolic rules. Indeed, these findings are consistent with the view that exemplar-based learning, whereby patterns of categorization and generalization are driven by similarity to known forms, appropriately characterizes the acquisition of inflectional morphology across typologically distinct languages.

Scandinavian languages (Danish, Icelandic, Norwegian and Swedish) offer yet another opportunity to examine the role of phonological similarity and type and token frequency for the acquisition and representation of verbal inflectional systems. These languages are quite similar to English (in their verbal inflection systems) in that they possess a very small class of exceptions and a very large class of suffixed verbs. However, they differ from English in that the suffixation process is not homogeneous but consists of two distinct classes. In this respect, they offer a natural experimental setting in which to investigate the acquisition process under conditions which are systematically different to English. Acquisition data from these languages may help shed further light on the nature of the mechanisms involved in the acquisition of inflectional systems crosslinguistically. In particular, these languages offer an opportunity to examine inflectional generalization when two processes of suffixation are potentially in competition with one another. For example, does the suffixation process applied to the larger class of verbs constitute the primary source of generalization to novel forms and errors on verbs that do not belong to that inflectional class? What role does the phonological form of a verb play in determining the pattern of errors in these languages? And how does the token frequency of individual verbs influence children's performance on these forms?

In this paper, we describe a study of the acquisition of past tense morphology in Icelandic and Norwegian. We begin with an overview of the processes of past tense inflection in these languages and then describe an elicitation task that tests children's knowledge of selected past tense forms in Icelandic and Norwegian. The elicitation task forms the basis of a crosssectional, experimental study involving children at different ages. Our goal is to examine the developmental profile of mastery of these past tense forms in the two languages and detail the pattern of errors produced by the children at different ages. We also offer a characterization of the factors that most influence the developmental profile and production errors for these children and relate these findings to symbolic and exemplar-based (network) models of inflectional learning. 
DESCRIPTION OF NORWEGIAN AND ICELANDIC PAST TENSE

MORPHOLOGY

Verbal morphology of Norwegian and Icelandic as compared to English

Norwegian and Icelandic are Germanic languages and share many basic characteristics with other Germanic languages, such as English. The three languages also differ in interesting ways from each other. In the following, we briefly outline those aspects of the verbal inflectional systems that are of relevance for the cross-linguistic study of children's acquisition of past tense inflections.

Like other Germanic languages, English, Norwegian, and Icelandic all honour a basic distinction between weak (often called regular) and strong (often called irregular) verbs. ${ }^{5}$ Weak verbs form the past tense through suffixation, whereas strong verbs form the past tense through other means, typically without a suffix, but with a vowel change in the stem. The number and types of strong verbs are comparable in the three languages, but whereas English only has one weak inflectional class, Norwegian and Icelandic have two main weak classes. In both languages, both weak classes are much larger than any strong class. However, of the two weak classes, one is clearly larger than the other, and also more productive (in the sense of assimilating new verbs in the language). Figure I presents an estimate of the different

Proportions of main verb classes

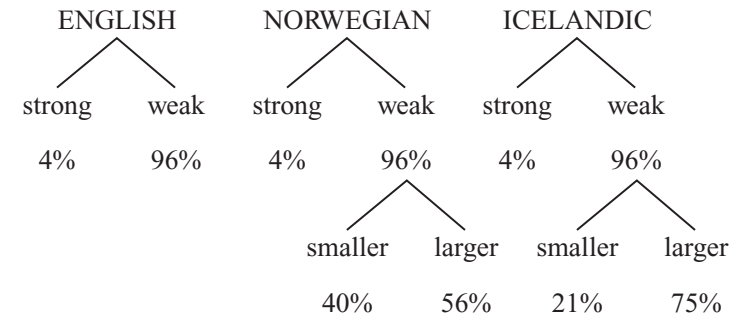

Fig. I. Proportions of main verb classes in English, Norwegian and Icelandic.

proportions of the verb classes, based on the most recent dictionaries for Icelandic and Norwegian (Íslensk orðtíðnibók, Magnússon \& Briem, I 99 I, ${ }^{6}$ Bokmålsordboka- $\mathrm{BO}-\mathrm{I} 986$ ) and recent studies of English (Pinker \& Prince, I 988, Marcus et al., 1992).

[5] We have chosen to use the classical terminology for Germanic languages, WEAK and STRONG, instead of the terms REGULAR and IRREGULAR often used in the literature.

[6] Thanks also to Eiríkur Rögnvaldsson for the use of his unpublished list of approximately 5000 Icelandic verbs. 
In English, the formal distinction between weak and strong verbs is based on whether they carry a suffix in the past tense or not. In Norwegian and Icelandic this distinction is based on whether they carry a SYLLABIC suffix: verbs carrying a syllabic suffix in the past tense are weak, those without a syllabic suffix are strong. (This entails that while weak verbs end in an unstressed syllable, strong verbs end in a stressed syllable.) Although strict criteria are often given for distinguishing between the different verb classes and subclasses in Norwegian and Icelandic, some verbs have alternative inflections, as both strong and weak, or as inflected according to both the larger and the smaller weak class. In the experiment designed for the present research, verbs with alternative inflections were avoided. In both languages, the larger weak classes have suffixes beginning with a vowel, while the smaller weak classes have suffixes beginning with a consonant. Table I presents examples from the paradigms of weak verbs in the three languages, and highlights points where they differ.

An important difference between the three languages concerns their morphological complexity. English has a relatively simple morphology, Norwegian is slightly more complex and Icelandic is a highly inflected language. Icelandic verbs are inflected for tense, mood, person, number, and voice, involving suffixes as well as vowel changes. An indication of the difference in morphological complexity is the number of different word forms in the weak verb paradigms, as illustrated in Table $\mathrm{I}$. The paradigm of a weak verb contains four word forms in English, seven in Norwegian, and at least i 8 word forms in Icelandic. The difference in morphological complexity is even more pronounced in the strong verb paradigm which may contain up to 40 forms in Icelandic. Furthermore, vowel changes, which are almost exclusively found in strong verbs in English and Norwegian, are found in both strong and weak verbs in Icelandic due to general morphophonological processes. For instance, /a/ changes to /ø/ when the inflectional ending in the following syllable starts with an /y/: e.g. ég kasta 'I throw' vs. við köstum 'we throw'; mamma 'mummy, nom.' vs. mömmu , 'mummy, acc./gen./dat.'.

The bare stem is more prominent in English verb paradigms than in Norwegian and Icelandic. In English, several word forms are represented by the bare stem, in particular the infinitive, the imperative, and the simple present tense (except the 3 rd p. sg.). In Norwegian, the verb stem surfaces in just one word form, the imperative, and in Icelandic, there is no word form corresponding to the bare stem. Strictly speaking, the imperative singular is the same form as the bare stem. This form, however is not used without the suffixed 2 nd p. pronoun, except in very formal/old texts.

Figure I also shows the relative sizes (type frequency) of the two weak verb classes in each language. In both languages, there is clearly a dominant class which constitutes the majority inflectional process. However, in Norwegian, 
TA В LE I. Paradigms for weak verbs in English, Norwegian, and Icelandic

\begin{tabular}{|c|c|c|}
\hline $\begin{array}{l}\text { English } \\
\text { stem (= inf./pres./imp.) } \\
\text {-ing-form } \\
\text {-s form (3rd p. sg. pres.) } \\
\text {-ed form (past/past part.) }\end{array}$ & \multicolumn{2}{|c|}{$\begin{array}{ll}\text { One single weak inflectional class } \\
\text { dance } & \text { call } \\
\text { dancing } & \text { calling } \\
\text { dances } & \text { calls } \\
\text { danced } & \text { called }\end{array}$} \\
\hline & \multicolumn{2}{|c|}{ Two weak inflectional classes } \\
\hline \multirow[t]{2}{*}{$\begin{array}{l}\text { Norwegian } \\
\text { stem (= imperative) } \\
\text { infinitive } \\
\text { present } \\
\text { past } \\
\text { past participle } \\
\text { pres. participle } \\
\text { passive }\end{array}$} & $\begin{array}{l}\text { Larger } \\
\text { kast } \\
\text { kaste } \\
\text { kaster } \\
\text { kastet } \\
\text { kastet } \\
\text { kastende } \\
\text { kastes }\end{array}$ & $\begin{array}{l}\text { Smaller } \\
\text { rop } \\
\text { rope } \\
\text { roper } \\
\text { ropte } \\
\text { ropt } \\
\text { ropende } \\
\text { ropes }\end{array}$ \\
\hline & \multicolumn{2}{|c|}{ Two weak inflectional classes } \\
\hline $\begin{array}{l}\text { Icelandic } \\
\text { stem } \\
\text { infinitive \& pres.ind.3. p.pl. } \\
\text { pres.ind. I.p. sg. } \\
\text { pres.ind. } 2 \text { \& } 3 \text { p. sg. } \\
\text { pres.ind. \& subj. I.p. pl. } \\
\text { pres.ind. \& subj. 2.p. pl. } \\
\text { pres.subj. I. \& 3.p. sg.; 3.p. pl. } \\
\text { pres.subj. 2.p. sg. } \\
\text { past ind. \& subj. I.\& 3.p. sg. } \\
\text { past ind. \& subj. 2.p. sg. } \\
\text { past ind. \& subj. I.p. pl. } \\
\text { past ind. \& subj. 2.p. pl. } \\
\text { past ind. \& subj. 3.p. pl. } \\
\text { imperative sg. } \\
\text { imperative. pl. } \\
\text { passive ind. sg./pl. } \\
\text { passive subj. sg./pl. } \\
\text { pres.participle } \\
\text { past participle sg. }\end{array}$ & $\begin{array}{l}\text { Larger } \\
\text { kast } \\
\text { kasta } \\
\text { kasta } \\
\text { kastar } \\
\text { köstum } \\
\text { kastið } \\
\text { kasti } \\
\text { kastir } \\
\text { kastaði } \\
\text { kastaðir } \\
\text { köstuðum } \\
\text { köstuðuð } \\
\text { köstuðu } \\
\text { kastaðu } \\
\text { kastiði } \\
\text { kastast } \\
\text { kastist } \\
\text { kastandi } \\
\text { kastað }\end{array}$ & $\begin{array}{l}\text { Smaller } \\
\text { dæm } \\
\text { dæma } \\
\text { dæmi } \\
\text { dæmir } \\
\text { dæmum } \\
\text { dæmið } \\
\text { dæmi } \\
\text { dæmir } \\
\text { dæmdi } \\
\text { dæmdir } \\
\text { dæmdum } \\
\text { dæmduð } \\
\text { dæmdu } \\
\text { dæmdu } \\
\text { dæmiði } \\
\text { dæmast } \\
\text { dæmist } \\
\text { dæmandi } \\
\text { dæmt }\end{array}$ \\
\hline
\end{tabular}

the difference in size between the two weak classes is less pronounced than in Icelandic.

Reliable estimates for the token frequencies of individual verbs in spoken Icelandic and Norwegian are not readily available. For Icelandic we used Íslensk orðtíðnibók (I99I). These frequencies are based on written texts from Ioo different sources, ranging from children's books to law texts. For Norwegian, a combination of written and spoken language frequency counts was used: Heggstad (1982) which is a frequency dictionary of written Bokmål, based on newspaper texts, and TAUS (1978) which is a database of adult spoken language in the Oslo dialect, but restricted in size. The lack of 
reliable frequency estimates for spoken language, and the fact that all frequencies are based on adult material only, may be a problem for the assessment of token frequency effects in child language data. However, we used the best sources available.

\section{Norwegian verb morphology}

Norwegian has several dialects, and two written norms: Bokmål and Nynorsk. The dialect described and investigated here is the Bokmål variety of the dialect spoken in the capital, Oslo. To a large extent the description of this dialect also covers the other dialects spoken in Eastern Norway.

Weak verbs. $96 \%(n=4600)$ of the Norwegian verbs are weak and can be classified into two classes. The weak class with the highest type frequency (WL, $56 \%$ of all verbs) carries a past tense suffix beginning with a vowel, i.e. with - et / et/ or $-a / \mathrm{a} /$ - the choice between these being sociolinguistically and/or stylistically conditioned. The addition of the suffix in this class does not entail any change in the stem. Examples of verbs from this class are kaste 'throw' kastet (or kasta), hoppe 'jump' hoppet (or hoppa), plukke 'pick' $\sim$ plukket (or plukka).

The weak class with the lower type frequency (WS, $40 \%$ of all verbs) carries a past tense suffix beginning with a dental/alveolar consonant, -te /te/ and $-d e / \mathrm{de} /$ - their distribution being mainly phonologically conditioned. The addition of the suffix in this class is often accompanied by a shortening of the stem vowel, as well as certain phonotactically motivated assimilations between stem and suffix consonants. For example, for all verbs with a stem ending in $/ \mathrm{r} /$, the addition of $-/$ te/ triggers an automatic assimilation giving -/te/ with a retroflex stop as a result: kjøre/çø:re/'drive' becomes kjørte /çø: te/ 'drove' in the past tense, and in rope/ru:pe/ 'call' vowel shortening gives ropte / rupte/ in the past tense. Other examples of verbs from this class are bake 'bake' $\sim$ bakte, bygge 'build' $\sim$ bygde, sy 'sew' $\sim$ sydde, reparere 'repair' $\sim$ reparerte.

The WL class functions as a default class, in the sense that almost any verb, irrespective of phonological patterning, may be inflected according to this class. (Two general exceptions to this are mentioned below). This is also the class which is generally productive, in the sense that most new verbs entering the language also fall into this class.

The WS class is phonologically less diverse than the WL class. There are two subgroups of verbs in the WS class which are phonologically homogeneous. One group consists of all weak verbs with a monosyllabic infinitive $(n=70)$ : (e.g. sy 'sew', gre 'comb', nà 'reach'). Verbs of this type which are weak belong to the WS class, taking the -de suffix. The second group has a stem ending in -er/er/, giving verbs with infinitives in -ere (e.g. reparere 'repair', markere 'mark', sortere 'sort'). This group consists of verbs derived 
with the special (latinate) stressed affix -er-, which is a productive process for deriving loan verbs in Norwegian. For these verbs, the WS inflectional pattern is fully productive. Thus, this subgroup of WS verbs is actually quite large $(n=1500)$ and growing, accounting for nearly $80 \%$ of the verbs in the WS class in Norwegian. However, most -ere verbs have a low token frequency. If we exclude the -ere verbs, the proportion of WS verbs as compared to WL verbs drops drastically, to approximately $8 \%$ (cf. Figure 2).

Weak verbs in Norwegian Bokmål: an overview

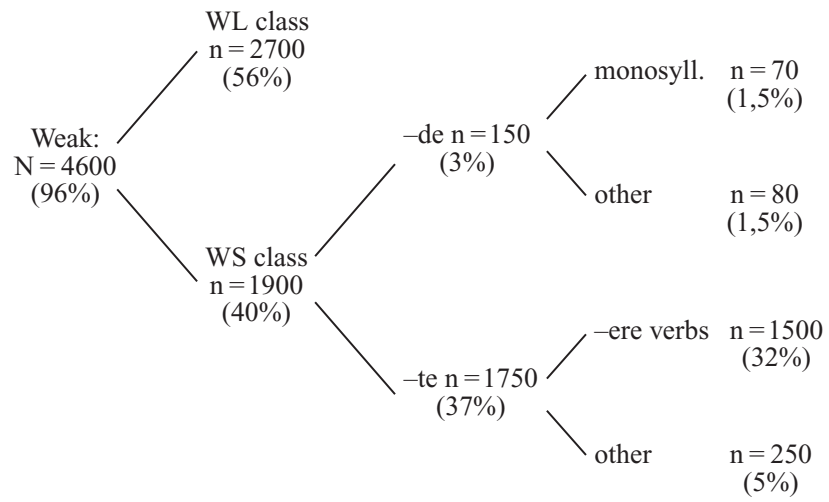

Fig. 2. Weak verbs in Norwegian

For the rest of the WS verbs (about 350 verbs) there are some more subtle phonological cues in the stems of the weak verbs, which may help in distinguishing between the two classes. As for vowel quantity, there is a strong correlation between the length of the stem vowel and verb class: in the WL class, about $80 \%$ of the verbs have a short stem vowel, and only $20 \%$ a long one, while the opposite is the case for the WS class - around $80 \%$ of these verbs have a long stem vowel. In addition, in some cases vowel quality is a good predictor of class membership: for example, in the WL class, /a/ is the most frequent stem vowel, found in $20 \%$ of the verbs, while there is only one verb with an /a/ stem in the WS class (kalle 'call' $\sim$ kalte); in the WS class, /ø:/ is the most frequent stem vowel, while this vowel is very rare in WL verbs. Furthermore, in the WS class, the set of stem final consonants is somewhat more restricted than that of the WL class. Verbs from the WS class taking the -te suffix have stems ending in unvoiced stops, nasals, liquids or $/ \mathrm{s} /$, while verbs taking the -de suffix have stems ending in a long, stressed vowel, or in one of the consonants /gvj/. Verbs with stem final /b, t, n, J, f/ do not occur in the WS class. Similarly, verbs with stem-final consonant clusters are very rare in the WS class (Hagen, I994). 
In sum, such phonological restrictions makes the WS class phonologically less open than the WL class; however, to a large extent these restrictions are only tendencies and do not supply clearcut boundaries between the two classes.

Thus, with the exception of -ere verbs, it is not possible to define exact criteria of class membership for weak verbs on a purely phonological basis in Norwegian. Verbs may rhyme with each other, but are inflected in different ways: (e.g. glane 'look' $\sim$ glante, but rane 'rob' $\sim$ ranet; spille 'play' $\sim$ spilte, but trille 'roll' $\sim$ trillet). However, there are strong tendencies supplying phonological patternings that are reliable cues to a varying degree (see below for examples of cue validity estimates including strong verbs).

An overview of the structure of the inflectional class system for weak verbs in Norwegian Bokmål based on BO, is given in Figure 2. Percentages are of the total number of verbs listed in BO, i.e. 4800 verbs. Excluded from the count are verbs in the dictionary that were unknown to us.

Strong verbs. Only $4 \%$ of the Norwegian verbs listed in BO are strong $(n=200)$. We have chosen a subclassification based essentially on the stem vowel in the past tense form, i.e. a product-oriented definition. One subgroup, however, is partly source-oriented-the so-called No Change class, characterized as having the same stem vowel in the infinitive and the past tense. A source-oriented definition takes as its point of departure a baseform which undergoes a process to create a new form. This type of definition focuses on the baseform (the source) and the process changing it. A product-oriented definition focuses on the result of the process (the product) and uses this as its point of departure, irrespective of baseform and process (see Bybee, I995). The subgroups are shown in Table 2 listed in

TA B LE 2. Strong verbs in Norwegian

\begin{tabular}{|c|c|c|c|c|}
\hline $\begin{array}{l}\text { Sub- } \\
\text { group }\end{array}$ & $\begin{array}{l}\text { Inf.stem } \\
\text { vowel }\end{array}$ & $\begin{array}{l}\text { P'T stem } \\
\text { vowel }\end{array}$ & Examples & $\begin{array}{l}\text { Number } \\
\text { of verbs }\end{array}$ \\
\hline I & $/ \mathrm{i}, \mathrm{e}, \mathrm{y} /$ & $/ \mathrm{a} /$ & $\begin{array}{l}\text { drikke 'drink' } \sim \text { drakk, dette 'fall' } ~ \\
\text { datt, synge 'sing' } \sim \text { sang }\end{array}$ & 40 \\
\hline 2 & /i:/ & /e:/ (/æi/) & bite 'bite' $\sim$ bet/beit* & 33 \\
\hline 3 & $/ \mathrm{y}: /$ & /ø:/ (/øу/) & flyte 'fleet' $\sim$ fløt/fløyt* & 27 \\
\hline 4 & /a:, o:, e:, æ/ & /u:/ & $\begin{array}{l}\text { dra 'pull' } \sim \text { dro, le 'laugh' } \sim \text { lo, slà 'hit' } \\
\sim \text { slo }\end{array}$ & I 4 \\
\hline 5 & /e, e:,i:, æ:/ & /a:/ & bare 'carry' $\sim$ bar, $s i$ 'say' $\sim s a$ & 9 \\
\hline 6 & $/ \mathrm{a}, \mathrm{o}, \mathrm{o}:, \mathrm{e}:, \varnothing: /$ & No Change & $\begin{array}{l}\text { lope 'run' } \sim \text { lop, komme 'come' } \sim \text { kom, } \\
\text { sove 'sleep' } \sim \text { sov }\end{array}$ & 9 \\
\hline 7 & 'The Rest' & & se 'see' $\sim$ så, gå 'go' $\sim$ gikk & 5 \\
\hline
\end{tabular}

* The choice between a diphthong and a long vowel in the past tense of these verbs is sociolinguistically conditioned. 
order of descending type frequency. We have only counted non-compound verbs, and only those which are judged to be in use as strong verbs in the spoken Oslo dialect today. For this reason, and also because our definition of strong verbs deviates from the one that seems to underlie the $\mathrm{BO}$ definition, the total number of verbs listed below is lower than the number given in BO $(n=\mathrm{I} 36)$. In the subgroup called 'The Rest' are listed strong verbs which do not seem to belong to any group - these all have a high token frequency.

There are three subgroups with more than 27 verbs each, and three (excluding 'The Rest') with less than i 4 verbs. The phonological coherence (internal consistency) within each subgroup also varies: in some subgroups, (e.g. groups 2 and 3), all verbs have the same stem vowel in the infinitive, while in others (e.g. groups I and 4), the verbs have several different stem vowels in the infinitive. The verbs in the No Change subgroup (in Norwegian, as well as in Icelandic, see below) have a low phonological coherence, in that they neither have stem vowels nor stem consonants in common - the similarity between them consists in their each having the same stem in the infinitive and the past tense. In this way, they differ from the No Change verbs in English, which in addition to preserving their stem vowel, also have the specific characteristic in common that they all end in an alveolar stop. The No Change group in English is also much larger, containing 20 verbs, while the Norwegian group contains only nine verbs, (and the Icelandic one even fewer).

To the extent that the verb groups have a very low phonological coherence, one could question whether these verbs function as a group at all: the less phonologically homogeneous they are, the less probably they are perceived as one pattern. Although they have the same past tense vowel, they might just as well be listed as separate verbs.

Cues to class membership. Summing up, for Norwegian verbs certain patterns emerge as possibly important cues for class membership, among which we will mention three: I. The single most predictive (and the only I $00 \%$ predictive class) is the subclass of -ere verbs: all -ere verbs are WS verbs. 2. For verbs with a monosyllabic infinitive form (only 94 in all) there is a $75 \%$ chance that the verb is a WS verb, and an $18 \%$ chance that it is a strong verb (the remaining $7 \%$ have alternate inflections between the two) - these verbs are never inflected according to the WL pattern. 3 . As for vowel quantity, (excluding the -ere verbs), $72 \%$ of all Norwegian verbs have a short infinitive stem vowel. Among these, $95 \%$ are $\mathrm{WL}$ verbs, $3 \%$ are $\mathrm{WS}$ verbs, and $2 \%$ are $\mathrm{S}$ verbs. $28 \%$ of the verbs have a long infinitive stem vowel here $61 \%$ have a WL inflection, $29 \%$ have a WS inflection and $10 \%$ are $\mathrm{S}$ verbs. For a Norwegian child, using the short infinitive stem vowel as a cue to membership of the WL class will result in a correct classification $95 \%$ of the time. For the remaining I/ 4 of the verbs, i.e. those with a long vowel, the 
picture is much less clearcut: the WL pattern will still be correct for more than $60 \%$ of the verbs, but both the WS pattern and the $\mathrm{S}$ patterns are possible candidates.

Icelandic verb morphology

Weak verbs. Like Norwegian, Icelandic has two main weak inflectional classes. The larger weak class (WL) takes the past tense suffix - aði /aðı/( Ist/3rd p.sg.), an unstressed two-syllable suffix beginning with a vowel. Approximately $75 \%$ of Icelandic verbs belong to this class and new verbs in the language also are assimilated into this class. The WL class undergoes the smallest degree of phonological change needed for the past tense inflection relative to the stem. The past tense suffix is easily segmentable and it starts with the same vowel as the infinitive ending for most of the past tense paradigm. No changes are needed for the consonants of the stem (cf. Table I), but due to the general morphophonological processes mentioned above, verbs with the vowel $-a-/ \mathrm{a} /$ in the stem change the $-a$ - to $-\ddot{o}-/ \varnothing /$ in the past tense for all persons in the plural. Examples of verbs from this class are kasta 'throw' $\sim$ ég kastað $i$ 'I threw' við köstuðum 'we threw', and hорpa 'jump' ég hорpað $i$ 'I jumped' við hорpиðиm 'we jumped'.

The smaller weak class (WS) takes a one-syllable past tense suffix starting with a dental/alveolar consonant, i.e. $-t i / \mathrm{tI}_{\mathrm{I}}$, $-d i / \mathrm{d}_{\mathrm{I}} /$ or $-ð i / \partial_{\mathrm{I}} /$ ( I st/3rd p.sg.), depending mainly on the final consonants in the stem. The stem final consonant is often assimilated to that of the suffix, so that the suffixes of verbs in the WS class are not as easily segmented from the stem as the WL suffix. Examples of verbs in this class are hlýða /liða/ 'obey' hlýddi /lid:ı/, sigla /sıgla/ 'sail' $\sim$ sigldi /sıldı/, benda /benda/ 'point' $\sim$ benti /bentı/, keyra /keira/ 'drive' keyrð $i$ /keirðı/.

Like their Norwegian counterparts, all monosyllabic weak verbs ending in a stressed vowel in the infinitive $(n=24)$ are inflected according to the WS class. On the other hand, all (non-compound) verbs with three or more syllables belong to the WL class. Apart from these constraints, there are no strict phonological conditions for membership in either of the two weak classes, i.e. all other verbs could in principle go into either one. As it turns out, however, there are tendencies for phonological configurations to be predictive of class membership. For instance, weak verbs with the stem vowels $a$ /a/, au /øi/, á /au/,o /o/,ó /ou/, u/y/, ú/u/, ö/ø/7 - (totalling $53 \%$ of all weak verbs) overwhelmingly $(95 \%)$ belong to the WL class. Verbs with other stem vowels $e$ /e/,é /je/,ei /ei/, ey/ei/, $i, / \mathrm{I} /, i / \mathrm{i} /, y / \mathrm{s} /, y / \mathrm{i} /$, $a /$ ai/ are more equally divided between the two classes $(57 \%$ in WL, $43 \%$

[7] All these vowels can also be long, but vowel length is not distinctive in Icelandic - only consonant length is. 
in WS). Some additional regularities in the class membership for these verbs take into account both stem vowels and the consonants following them (Gíslason, I 992). An overview of the distribution of weak verbs into subclasses is provided in Figure 3 .

Strong verbs. The number of strong verbs listed in classical textbooks of Icelandic is approximately 200. Only around I 50 of them are used in modern Icelandic (Magnússon \& Briem, r 99I). Because of the abundance of different forms in the strong verb inflection in Icelandic it is hard to classify these verbs in a consistent, yet economical, way. However, as we did for Norwegian, we have chosen a strictly synchronic, essentially productoriented definition, based on the vowel in the $3 \mathrm{rd} \mathrm{p.sg.} \mathrm{of} \mathrm{the} \mathrm{past} \mathrm{tense.} \mathrm{In}$ this classification, we have included the subphonemic distinction of vowel length. This was done to make the comparison with Norwegian easier. In Table 3, an overview of subgroups including three or more verbs is listed. Only non-compound verbs in use in contemporary Icelandic are included $(n=\mathrm{I} 56)$.

The subgroups have differing type frequencies: three subgroups include approximately 30 verbs (i.e. the subgroups with a PT 3 rd p. sg. vowel of [a], [øi:], and [ei:], respectively) two have i6 (P'T vowel [a:]) and 22 verbs (PT vowel [ou:]) each, and the rest have seven or less verbs.

The phonological coherence (internal consistency) within groups is variable. In subgroup 3 all verbs have the same stem vowel in the infinitive, and in subgroup 2, the vowels in the infinitive are similar-back and rounded, alternatively starting with $\mathrm{a} / \mathrm{j} /$. In the others, the verbs have several different stem vowels in the infinitive - subgroup I has both front, close vowels and open, back vowels, while other subgroups are even more varied. In certain subgroups (2, 4, 6, 7, 8, 9 and ro) a vowel shift occurs between the infinitive and the present tense and in most subgroups consonant changes occur in addition to vowel shifts, e.g. binda 'tie' $\sim$ batt, standa 'stand' $\sim$ stóo.

Cues to class membership. For Icelandic, too, certain phonological patterns are identifiable as possible cues to verb class membership: I. All non compound verbs with three or more syllables belong to the WL class. 2 . Verbs with a monosyllabic infinitive (27 in all) are overwhelmingly (24) WS verbs, while three are strong - like in Norwegian, these verbs never receive a WL inflection. 3. For the rest of the verbs the quality of the stem vowel may be one cue to class membership. For example, for verbs with the stem vowels $a / \mathrm{a} /$, au /øi/, á /au/, o/o/,ó/ou/, u/y/, ú/u/, ö/ø/, $(n=2645), 93 \%$ are WL, $4 \%$ are WS, and $3 \%$ are strong verbs, yielding a very high cue validity for the WL class. For verbs with the stem vowels $e / \mathrm{e} /, i / \mathrm{I} /$, and $y / \mathrm{I} /(n$ 
Weak verbs in Icelandic: an overview

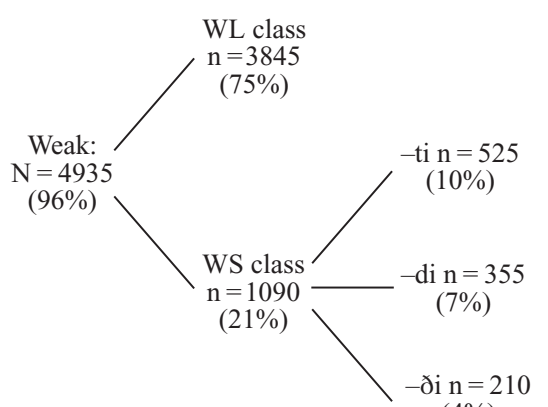

$(4 \%)$

monosyllabic $n=23$

other $\mathrm{n}=187$

Fig. 3. Weak verbs in Icelandic

TABLE 3. Strong verbs in Icelandic

\begin{tabular}{|c|c|c|c|c|}
\hline $\begin{array}{l}\text { Sub- } \\
\text { group }\end{array}$ & $\begin{array}{c}\text { Infinitive } \\
\text { stem vowel(s) }\end{array}$ & vowel & $\begin{array}{l}\text { P'T 3.p.sg } \\
\text { Examples }\end{array}$ & $\begin{array}{l}\text { Number } \\
\text { of verbs }\end{array}$ \\
\hline I & {$[\mathrm{e}, \mathrm{I}, \mathrm{ja}, \mathrm{jau}]$} & {$[\mathrm{a}]$} & $\begin{array}{l}\text { bresta 'break' } \sim \text { brast, vinna 'work, win' } \\
\sim \text { vann, gjalda 'pay' } \sim \text { galt, skjálfa } \\
\text { 'shiver' } \sim \text { skalf }\end{array}$ & 30 \\
\hline 2 & {$[\mathrm{ou}:, \mathrm{u}:, \mathrm{jou}:, \mathrm{ju}:]$} & [øi: $]$ & $\begin{array}{l}\text { bjóða 'invite' } \sim \text { bauð, ljúga 'lie' } \sim \text { laug, } \\
\text { súpa 'drink' } \sim \operatorname{saup}\end{array}$ & 32 \\
\hline 3 & {$[\mathrm{i}:]$} & [ei:] & bita 'bite' $\sim$ beit, svikja 'betray' $\sim$ sveik & 29 \\
\hline 4 & {$[\mathrm{a}:, \mathrm{e}:, \mathrm{a}, \mathrm{e}, \mathrm{u}, \mathrm{ei}, \mathrm{ai}]$} & [ou: $]$ & $\begin{array}{l}\text { taka 'take' } \sim \text { tók, vefa 'weave' } \sim \text { óf, } \\
\text { standa 'stand' } \sim \text { stód, hefja 'start' } \\
\text { hóf, deyja 'die' } \sim \text { dó, hlceja 'laugh' } \\
\text { hló }\end{array}$ & 22 \\
\hline 5 & {$[\mathrm{e}:, \mathrm{o}:, \mathrm{I}]$} & {$[\mathrm{a}:]$} & $\begin{array}{l}\text { bera 'carry' } \sim \text { bar, sofa 'sleep' } \sim \text { svaf, } \\
\text { sitja 'sit' } \sim \text { sat }\end{array}$ & I6 \\
\hline 6 & [au:, ei:, i:] & {$[\mathrm{je}:]$} & $\begin{array}{l}\text { gráta 'cry' } \sim \text { grét, leika 'play' } \sim \text { lék, } \\
\text { víkja 'give way' } \sim \text { vék }\end{array}$ & 7 \\
\hline 7 & {$[\mathrm{au}, \mathrm{a}, \mathrm{au}:]$} & {$[\mathrm{je}]$} & $\begin{array}{l}\text { ganga 'walk' } \sim \text { gekk, halda 'hold' } \sim \text { hélt } \\
\text { fá 'get' } \sim \text { fékk }\end{array}$ & 5 \\
\hline 8 & {$[\varnothing \mathrm{i}:, \varnothing]$} & [jou: $]$ & $\begin{array}{l}\text { hlaupa 'run' } \sim \text { hljóp, höggva 'shop } \\
\text { down' } \sim \text { hjó }\end{array}$ & 4 \\
\hline 9 & {$[\mathrm{I}, \mathrm{e}, \mathrm{au}:, \mathrm{je}:]$} & {$[\mathrm{au}:]$} & $\begin{array}{l}\text { liggja 'lie down' } \sim \text { lá, sjá 'see' } \sim \text { sá, } \\
\text { bregða 'startle' } \sim \text { brá, éta 'eat' } \sim \text { át }\end{array}$ & 4 \\
\hline IO & {$[\varnothing, 0]$} & (No Change) & $\begin{array}{l}\text { stökkva 'jump' stökk, koma 'come' } \\
\text { kom }\end{array}$ & 4 \\
\hline I I & 'The Rest' & & & 3 \\
\hline
\end{tabular}


$=\mathrm{I} 4 \mathrm{I} 2$ ), the distribution is $62 \% \mathrm{WL}, 35 \% \mathrm{WS}$ and $3 \% \mathrm{~S}$ verbs, giving a less strong cue validity, but still one in favour of the WL class, while for verbs with $e /$ ai / and $e y /$ ei/ as stem vowels $(n=409)$, the distribution is reversed with $32 \% \mathrm{WL}, 68 \%$ WS and two single strong verbs. However, in spite of these cues being relatively strong, the fact that they are based on vowel quality may reduce their actual value for the Icelandic child. As already mentioned, the inflectional system of Icelandic involves an abundance of vowel changes in the verbal paradigms, in particular for the strong verbs, but also for some weak verbs. For this reason, the reliability of vowel quality of the infinitive form as a cue is reduced. Other cues, concerning stem consonants or vowel quantity, may possibly be more reliable, but these factors require more investigation.

OVERVIEW OF EXPERIMENTAL STUDY

In the remainder of this paper, we describe an experimental study of the use of past tense forms by Norwegian and Icelandic children. An adaptation of the elicitation task employed by Bybee \& Slobin (I982) is used to tap the knowledge of past tense forms in four-, six- and eight-year-old children. We have selected a sample of verbs that represent the main classes described in the above linguistic outline of the two languages. Furthermore, we have chosen to compare children's performance on verbs that vary in well-defined ways in an attempt to identify the source of any variations over developmental time. Other studies of the acquisition of inflectional morphology have identified factors such as type frequency, token frequency and phonological coherence as important determinants of the acquisition process. The verbal stimuli used in the current study, therefore, also vary along these dimensions in a systematic fashion, to the extent that the characteristics of the languages permit.

In addition, Norwegian and Icelandic provide a natural environment to investigate other factors that can impact upon acquisition. For example, phonological factors like salience and segmentability may be important: the more easily a morphological marker can be segmented from the stem, the more easily it may be identified and acquired. Similarly, phonological cues which help distinguish or identify the verb classes may be of importance. Finally, the variation in morphological complexity, as well as in the relative size and composition of weak classes, occurring naturally in the input to Norwegian as compared to Icelandic children, offer a natural laboratory setting to study the effect of these factors on the acquisition process.

Our main goal is to provide a characterization of Norwegian and Icelandic children's knowledge of past tense forms as demonstrated in an elicitation task with a view to identifying the overall profile of development of different types of verbs, the factors that contribute to that development and likely sources of error in past tense production. 
METHOD

Elicitation task

Parallel experiments were designed for Norwegian and Icelandic, eliciting past tense forms of cognate or similar verbs in the two languages. We used a picture elicitation task similar to that of Berko (1958) and Bybee \& Slobin ( 1982), where the child is shown a picture of someone performing an action. The experimenter says: 'This is a boy who knows how to - $-\mathrm{He}$ is - ing. $\mathrm{He}$ did the same thing yesterday. What did he do yesterday?' And the child is encouraged to respond with the past tense form of the verb: 'He - .' The actual phrasing of the cue in Norwegian and Icelandic differs from the English one because of language differences (see Appendix I).

\section{Subjects}

Three groups of children were tested, at 4,6 and 8 years of age, with approximately 30 children in each age group and similar numbers of boys and girls. Exact numbers in each group, mean ages and standard deviations are shown in Table 4.

TAB LE 4. Subjects in the elicitation task

\begin{tabular}{|c|c|c|c|c|c|c|c|c|c|c|}
\hline & \multicolumn{5}{|c|}{ Norwegian } & \multicolumn{5}{|c|}{ Icelandic } \\
\hline & Boys & Girls & Total & $\begin{array}{l}\text { Mean } \\
\text { age }\end{array}$ & S.D. & Boys & Girls & Total & $\begin{array}{c}\text { Mean } \\
\text { age }\end{array}$ & S.D. \\
\hline Four-year-olds & I 4 & I 4 & 28 & $4 ; 4 \cdot 4$ & $0 ; 3 \cdot 5$ & I 5 & 17 & 32 & $4 ; 2.26$ & $0 ; \mathrm{I} .20$ \\
\hline Six-year-olds & I 5 & I 4 & 29 & $6 ; 3 \cdot 15$ & $0 ; 2.10$ & I 5 & I 5 & 30 & $6 ; 3 \cdot 9$ & $0 ; \mathrm{I} .2 \mathrm{I}$ \\
\hline Eight-year-olds & 20 & I9 & 39 & $8 ; 3.0$ & $0 ; 1.27$ & I 5 & I 5 & 30 & $8 ; 3 \cdot 3$ & $0 ; 1.23$ \\
\hline
\end{tabular}

The subjects were recruited from preschools and schools in middle class areas in the two capitals, Oslo and Reykjavík. The Norwegian children were chosen from families where both parents spoke the East Norwegian dialect.

Verbs

Each child was tested individually on approximately 60 verbs. The verbs were presented in random order, the same for all children. In order to control for tiredness during testing, half of the children were presented with the last thirty verbs first. This method of presentation closely resembles the randomization procedures used in a similar elicitation task by Bybee \& Slobin (1982) and Orsolini et al. (r 998). It should be noted, however, that 
using the same random order of presentation of stimuli for all children has the potential to result in spurious order effects. We therefore report below an analysis aimed at identifying whether any local sequencing effects occur. Before the testing started, the children were tested on a few warm-up verbs to check that they understood the test, and that they could inflect for tense. The warm-up verbs did not rhyme with any of the verbs in the experimental test list.

Verbs from all the three main verb classes (Strong verbs (S), the Smaller Weak class (WS), and the Larger Weak class (WL)) were included in the test. Type frequencies for the classes thereby varied from low (S) through medium (WS) to high (WL). Approximately half of the verbs were strong and half were weak, with an approximately equal number from each of the two weak classes. In the Norwegian test there were 27 strong verbs, I 7 WS verbs and $\mathrm{I} 6 \mathrm{WL}$ verbs. In the Icelandic test there were 30 strong verbs, I 2 WS verbs and i 3 WL verbs. Among the weak verbs, we included both verbs which were phonologically similar to (rhyming with) a strong verb, and verbs which did not rhyme with any strong verb. Among the strong verbs, three different subgroups were tested: Two of the subgroups were chosen from those with the highest number of members (i.e. with a relatively high type frequency among the strong verbs) - one with a relatively low phonological coherence (SLP), and one with a high phonological coherence (SHP) as defined by the degree of phonological similarity between the members of each class (cf. Tables 2 and 3). The third group of strong verbs (Strong Idiosyncratic (SI)) was sampled from among different subgroups with few members each, including some No Change verbs.

For each subgroup of verbs we included an approximately equal number of high token frequency verbs and low token frequency verbs - except for the group of miscellaneous strong verbs (SI), which all had a relatively high token frequency. Since the token frequency norms available can not be considered to be entirely reliable, we felt it appropriate to select verbs which could be assigned in a dichotomous fashion to high and low frequency classes. In making this assignment, we used both the norms available to us and our own judgements about the token frequencies of the verbs in the two languages. The ten most frequent verbs in the languages were excluded from the test. ${ }^{8}$ The groups of verbs tested in each language are summarized in Table 5. A full list of all verbs included in the test for the two languages is given in Appendix 2.

It will be noted that the number of verbs in each category varies. Ideally, we would prefer to use a fully balanced experimental design with equal numbers in each category to be investigated. However, given the typological constraints of the languages and the number of verbs likely to be known to

[8] This was done to avoid a too strong token frequency bias. 
TABLE 5. Verb groups included in the test

\begin{tabular}{|c|c|c|c|c|}
\hline & & & \multicolumn{2}{|c|}{ Examples } \\
\hline & & & Norwegian & Icelandic \\
\hline I & SLP & $\begin{array}{l}\text { Strong verbs, high type frequency, low } \\
\text { phonological coherence }\end{array}$ & sitte $\sim$ satt & detta $\sim$ datt \\
\hline 2 & SHP & $\begin{array}{l}\text { Strong verbs, high type frequency, high } \\
\text { phonological coherence }\end{array}$ & fryse $\sim$ fros & bjóð $a \sim b a u ð$ \\
\hline 3 & SI & $\begin{array}{l}\text { Strong verbs from different low type } \\
\text { frequency subgroups }\end{array}$ & $\begin{array}{l}\text { ligge } \sim \text { lå } \\
\text { løpe } \sim \operatorname{løp}\end{array}$ & $\begin{array}{l}\text { liggja lá } \\
\text { stökkva } \sim \text { stökk }\end{array}$ \\
\hline 4 & WLR & $\begin{array}{l}\text { Weak larger class, rhyming with strong } \\
\text { verbs }\end{array}$ & titte $\sim$ tittet & hljóð $a \sim$ hljóðað $i$ \\
\hline 5 & WLN & $\begin{array}{l}\text { Weak larger class, not rhyming with strong } \\
\text { verbs }\end{array}$ & kaste $\sim$ kastet & kasta $\sim$ kastað $i$ \\
\hline 6 & WSR & $\begin{array}{l}\text { Weak smaller class, rhyming with strong } \\
\text { verbs }\end{array}$ & lyse $\sim$ lyste & gretta $\sim$ gretti \\
\hline 7 & WSN & $\begin{array}{l}\text { Weak smaller class, not rhyming with } \\
\text { strong verbs } \\
\text { strong verbs }\end{array}$ & kjøre $\sim$ kjørte & keyra $\sim$ keyrð $i$ \\
\hline
\end{tabular}

the child, this was not possible. Nevertheless, most of the analyses that we report below are based on categories containing at least $\mathrm{I} 2$ members, since failure to find differences between the subclasses of strong verbs (each containing 9-12 verbs) and between rhyming weak verbs ( 16 for each language) and non rhyming weak verbs ( $\mathrm{I} 7$ in Norwegian and nine in Icelandic) resulted in us collapsing the seven classes of verbs into three, i.e. Strong, Weak Smaller, Weak Larger.

\section{Recording and analysis of children's responses}

Two experimenters administered the elicitation task. One person interviewed the child while the second recorded the child's responses. Children's responses were coded on-line if they were correct. If the child made an error, this was coded phonetically for later classification. An audio tape recording was also made of all the child's responses in order to check the accuracy of the coder's original scoring.

Errors were assigned to six categories. These were:

I. Generalization of the larger weak pattern (GEN $>$ WL)

2. Generalization of the smaller weak pattern $(\mathrm{GEN}>\mathrm{WS})$

3. Generalization of a strong pattern $\quad(\mathrm{GEN}>\mathrm{S})$

4. No change of stem (NO CHANGE)

5. No answer

6. Non-past form

(NO ANSWER)

(NON-PAST) 
The first three error types are all overgeneralization errors. Errors of type GEN > WL all involved appending a 'vowel' suffix to an otherwise unaltered stem. Errors of type GEN > WS all involved appending a 'consonant' suffix to the stem. In some cases, morphophonological processes resulted in vowel shortening and/or final consonant assimilation in the stem, in accordance with the above description of this verb class. Errors of type GEN $>\mathrm{S}$ involved a vowel change in the stem and no syllabic suffix.

The last three error types reflect more general error strategies (though see discussion below). For NO ANSWER errors, the child offered no verb form at all. NON-PAST errors involved the use of infinitive or present tense instead of a past tense form. In the NO CHANGE errors the child used the infinitive stem in response. NO CHANGE errors in Norwegian and Icelandic seem to function differently from the No Change errors in English. In English, all verbs following the No Change pattern end in an alveolar consonant, and those verbs having a No Change error, (i.e. having a past tense form identical to the infinitive/present tense), tend to have a stem ending in an alveolar. In Norwegian and Icelandic, there are only a few verbs following a No Change pattern, and they do not end in the same consonant, nor do they have the same vowel patterns - their only similarity is that they have no syllabic past tense suffix, nor a vowel change from the infinitive/present tense stem: (e.g. hrökkva 'startle' hrökk, sove 'sleep' sov). The few verbs that undergo NO CHANGE errors do not have the same stem vowels as these. Since the phonological basis for this pattern is much less unified than for the other overgeneralization errors, we regard the NO CHANGE errors as a more general schema or strategy which the child may use when she encounters a problematic verb, something like: 'do as little as possible, as long as the result sounds like a possible past tense form' (Bybee \& Slobin, I982:274).

\section{RESULTS}

\section{Overall profile of development}

For each child, we calculated the number of correct responses, measured as the percentage of verbs correct in each group. In order to determine whether the particular random order of presentation of the stimuli resulted in spurious local order effects, we categorized each verb according to the classification of its antecedent stimulus (except of the first verb, of course). For this analysis Antecedents were classified as Strong, Weak Smaller or Weak Larger. The effect of Antecedent status was entered as an additional factor in the omnibus ANOVA reported below. We found no main effects of Antecedent status or interactions of Antecedent status with other factors in the ANOVA. We conclude therefore that it is highly unlikely that local order 
T АВ LE 6. Correct PT answers for all verbs by age group and language

\begin{tabular}{lccc}
\hline & Age 4 & Age 6 & Age 8 \\
\hline Norwegian & $51 \%$ & $72 \%$ & $90 \%$ \\
Icelandic & $38 \%$ & $77 \%$ & $89 \%$ \\
\hline
\end{tabular}

Tав LE 7. Correct PT answers by verb type and age: Norwegian children

\begin{tabular}{cccc}
\hline & $\begin{array}{c}\text { S class } \\
\text { Mean (S.D.) }\end{array}$ & $\begin{array}{c}\text { WS class } \\
\text { Mean (S.D.) }\end{array}$ & $\begin{array}{c}\text { WL class } \\
\text { Mean (S.D.) }\end{array}$ \\
\hline Age 4 & $33 \%(24 \%)$ & $47 \%(27 \%)$ & $85 \%(20 \%)$ \\
Age 6 & $60 \%(22 \%)$ & $71 \%(18 \%)$ & $94 \%(8 \%)$ \\
Age 8 & $86 \%(14 \%)$ & $91 \%(10 \%)$ & $96 \%(5 \%)$ \\
\hline
\end{tabular}

TABLE 8. Correct PT answers by verb type and age: Icelandic children

\begin{tabular}{cccc}
\hline & $\begin{array}{c}\text { S class } \\
\text { Mean (S.D.) }\end{array}$ & $\begin{array}{c}\text { WS class } \\
\text { Mean (S.D.) }\end{array}$ & $\begin{array}{c}\text { WL class } \\
\text { Mean (S.D.) }\end{array}$ \\
\hline Age 4 & I5\%(9\%) & $4 \mathrm{I} \%(3 \mathrm{I} \%)$ & $88 \%(\mathrm{II} \%)$ \\
Age 6 & $7 \mathrm{I} \%(22 \%)$ & $83 \%(\mathrm{I} \%)$ & $87 \%(\mathrm{I} \%)$ \\
Age 8 & $87 \%(\mathrm{I} \%)$ & $89 \%(7 \%)$ & $94 \%(6 \%)$ \\
\hline
\end{tabular}

effects have an impact on our general results and we exclude them from further analyses.

We performed a three-way mixed model ANOVA of correct performance including age, verb type and language as factors. As will be documented in more detail below, we found no effect of rhyme in the weak verbs and no differences in levels of correct performance across the three strong classes (except for a significantly lower level of performance on SHP in Norwegian). In the following overall analyses of correct performance, we have therefore simplified the presentation by collapsing the seven verb groups into threeStrong verbs and the Weak Larger and the Weak Smaller classes. We return to the fine-grained division of verb groups in our analysis of errors.

Tables 6, 7 and 8 provide the mean number of forms correct and standard deviations, given as percentages. Table 6 provides an overview of the correct performance in the two languages across the three age groups. Tables 7 and 8 provide a further breakdown of the children's performance by verb class.

We performed a 3-way ANOVA on this data including age (4, 6 and 8), verb type (Strong, Smaller Weak and Larger Weak) and language 
(Norwegian and Icelandic) as factors. The analysis revealed main effects of age $(F(2, \mathrm{I} 84)=260.84, p<0.000 \mathrm{I})$, and verb type $(F(2, \mathrm{I} 84)=\mathrm{I} 69.92, p<$ $0.000 \mathrm{I})$ but no main effect of language $(F(\mathrm{I}, \mathrm{I} 84)=0.30, \mathrm{p}=0.586)$. Significant two-way interactions were observed between age and language $(F(2,184)=5.85, p<0.003)$ and between age and verb type $(F(4, \mathrm{I} 84)=$ $44.9 \mathrm{I}, p<0.000 \mathrm{I})$. There was no two-way interaction between verb type and language $(F(2,184)=0.64, p=0.527)$. Finally, a three-way interaction was observed between age, verb type and language $(F(4, \mathrm{I} 84)=6.33, p<0.000 \mathrm{I})$.

Tukey-b post hoc tests revealed that differences in performance between age groups were all significant in both languages. In other words, both Norwegian and Icelandic children exhibited a monotonic improvement in performance across the three age groups. Similarly, post hoc tests comparing performance on verb types showed significant differences between the three types in both languages. In particular, Norwegian and Icelandic children produced the highest level of correct responses with the WL verbs, followed by the WS verbs and the lowest level of correct responses with the $\mathrm{S}$ verbs. The lack of any main effect of language indicates that the overall pattern of correct performance in Norwegian and Icelandic is similar. However, the interaction of age with language reflects a higher number of correct responses by the Norwegian children at age 4 only. The age $\mathrm{x}$ verb type interaction reflects an approaching ceiling effect for the WL class already by age 4. The lack of a two-way interaction between verb type and language indicates that the differences in performance across verb types are similar in both languages. Finally, the significant three-way interaction between age, verb type and language reflects a difference in the interaction between age and verb type between the two languages. In particular, the improvement in performance on the $\mathrm{S}$ verbs between the ages of 4 and 6 is more pronounced in Icelandic than in Norwegian. Furthermore, Norwegian children show a significant improvement on WS verbs between the ages of 6 and 8 whilst the Icelandic children do not. Finally, Norwegian children show a significant improvement on the WL class between the ages of 4 and 6 whilst the Icelandic children do not. All significant differences are based on Tukey-b post hoc tests with $\mathrm{p}<0.05$.

\section{Effect of rhyme on overall correct performance in the weak verbs}

A separate analysis was performed on the two main weak classes, each split into two groups according to whether they contained verbs rhyming with strong verbs or not; thus groups 4 and 6 are rhyming, and groups 5 and 7 non-rhyming (see Table 5). There were no main effects of rhyme, nor any interactions of rhyme with age, verb type (WS and WL) or language. We conclude that rhyme does not have an effect on the children's ability to correctly inflect the weak verbs in this elicitation task. 


\section{Token frequency effects}

Analyses of the impact of token frequency on children's responses were carried out separately for Norwegian and Icelandic. The SI subclass of strong was excluded from these analyses as they were all high frequency forms. Tables 9 and 10 provide the mean number of forms correct and

TAB LE 9. Correct answers by verb type and token frequency: Norwegian children

\begin{tabular}{cccl}
\hline & $\begin{array}{c}\text { S class } \\
\text { Mean (S.D.) }\end{array}$ & $\begin{array}{c}\text { WS class } \\
\text { Mean (S.D.) }\end{array}$ & $\begin{array}{c}\text { WL class } \\
\text { Mean (S.D.) }\end{array}$ \\
\hline Hi & $64 \%(28 \%)$ & $69 \%(23 \%)$ & $97 \%(6 \%)$ \\
Lo & $54 \%(31 \%)$ & $71 \%(23 \%)$ & $88 \%(12 \%)$ \\
\hline
\end{tabular}

TABLE Iо. Correct answers by verb type and token frequency: Icelandic children

\begin{tabular}{llll}
\hline & $\begin{array}{c}\text { S class } \\
\text { Mean (S.D.) }\end{array}$ & $\begin{array}{c}\text { WS class } \\
\text { Mean (S.D.) }\end{array}$ & $\begin{array}{c}\text { WL class } \\
\text { Mean (S.D.) }\end{array}$ \\
\hline Hi & $60 \%(\mathrm{I} 8 \%)$ & $76 \%(9 \%)$ & $98 \%(3 \%)$ \\
Lo & $55 \%(\mathrm{I} 7 \%)$ & $65 \%(26 \%)$ & $84 \%(\mathrm{I} 8 \%)$ \\
\hline
\end{tabular}

standard deviations for correct answers (given in percentages) by token frequency in the two languages.

For each language, a three-way mixed model ANOVA including age, frequency and verb type as factors was performed. For Norwegian, a main effect of frequency was observed $(F(\mathrm{I}, 90)=68.92, p<0.000 \mathrm{I})$ in addition to the main effects of age and verb types reported above. There was a significant interaction of frequency with verb type $(F(2,180)=32.42, p<0.000 \mathrm{I})$ but no interaction of frequency with age $(F(2,90)=2.08, p=0 . \mathrm{I} 3 \mathrm{I})$. Tukey post $h o c$ analyses revealed that the frequency effects occurred in both the $\mathrm{S}$ and WL verb classes but not the WS class. For the $\mathrm{S}$ and WL classes, high frequency verbs show a higher level of correct responses than low frequency verbs. For Icelandic, a main effect of frequency was observed $(F(\mathrm{I}, 90)=$ I03.98, $p<0.000 \mathrm{I})$ in addition to the main effects of age and verb type reported above. There was also a significant interaction of frequency and verb type $(F(2$, I 80$)=6.80, p<0.00 \mathrm{I})$ but no interaction of frequency with age $(F(2,90)=2.03, p<0.137)$. Tukey post hoc analyses revealed that the frequency effects occurred in all verb classes. High frequency verbs show a 
higher level of correct responses than low frequency verbs. However, this effect was more pronounced in the weak verb classes than the strong class.

We conclude that token frequency has a strong effect on Norwegian and Icelandic children's ability to inflect verbs correctly in this task. This effect is found in all age groups and all verb classes except in the WS class in Norwegian children. The frequency by verb type interactions in both languages is commensurate with other results of frequency by regularity interactions in the literature (see Seidenberg \& Bruck, I 990, Prasada, Pinker \& Snyder, 1990). In this study, the main effect of frequency remains in attenuated form for the weak verbs whereas in the studies of adults cited above the frequency effects are limited to the strong (irregular) verbs. However, in this study, as just noted, the only class of verbs which did not exhibit a frequency effect was the WS class in Norwegian. We will return to these results in the conclusion, particularly in the light of the patterns of errors observed in relation to the WS class.

\section{Errors}

For each child, we classified all errors as belonging to one of the six categories described above. We then calculated the error rate for each error type as the total number of errors for that type divided by the total number of responses produced by that child.

\section{Detailed analysis of error types}

Tables I I and I 2 provide a summary of the proportion of each error type at different ages in Norwegian and Icelandic, respectively.

Apart from a large proportion of NON-PAST errors in the Norwegian four-year-olds, the overwhelming majority of errors can be classified as overgeneralization errors, i.e. categories $\mathrm{I}-3$ described above. We focus our further detailed error analyses exclusively on these overgeneralization errors.

Tables 13 and I 4 provide a summary of the means and standard deviation of error rates for each of the three overgeneralization error types at different ages for both languages. We performed a three-way mixed model ANOVA of the distribution of incorrect responses including error type, age and language as factors and using the error rate scores for each child as the dependent measure in the analysis. The analysis revealed main effects of error type $(F(2,366)=72.95, p<0.000 \mathrm{I})$, age $(F(2, \mathrm{I} 83)=3.25, \mathrm{p}<0.04)$ and language $\left(F\left(\mathrm{I}, \mathrm{I} 8_{3}\right)=\mathrm{I} 0.53, p<0.00 \mathrm{I}\right)$. Significant two-way interactions were obtained for error type $\mathrm{x}$ language $(F(2,366)=22.99, p<0.000 \mathrm{I})$, error type $\mathrm{x}$ age $(F(4,366)=23.2 \mathrm{I}, p<0.000 \mathrm{I})$ and language $\mathrm{x}$ age $(F(2, \mathrm{I} 83)$ $=7.8 \mathrm{I}, p<0.00 \mathrm{I})$. Finally, a significant three-way interaction of error type $\mathrm{x}$ age $\mathrm{x}$ language was observed $(F(4,366)=5.75, p<0.000 \mathrm{I})$. The main 
ACQUISITION OF ICELANDIC AND NORWEGIAN PAST TENSE

T A B LE I I. Proportions of error types by age: Norwegian children

\begin{tabular}{cccccccc}
\hline & & & & \multicolumn{2}{c}{$\begin{array}{c}\text { No } \\
\text { change }\end{array}$} & $\begin{array}{c}\text { No } \\
\text { answer }\end{array}$ & Non-past \\
\hline Age 4 & 822 & $44 \%$ & I $2 \%$ & $2 \%$ & I $\%$ & $4 \%$ & $38 \%$ \\
Age 6 & 483 & $52 \%$ & $27 \%$ & $9 \%$ & $2 \%$ & $2 \%$ & $7 \%$ \\
Age 8 & 235 & $37 \%$ & $44 \%$ & I $3 \%$ & - & $2 \%$ & $4 \%$ \\
\hline
\end{tabular}

TABLE i2. Proportions of error types by age: Icelandic children

\begin{tabular}{lccccccc}
\hline & & & & & No & No \\
change & answer & Non-past \\
\hline Age 4 & I 088 & $62 \%$ & $30 \%$ & I $\%$ & $2 \%$ & I $\%$ & $4 \%$ \\
Age 6 & 378 & $22 \%$ & $61 \%$ & I $2 \%$ & $3 \%$ & I $\%$ & \\
Age 8 & I 82 & I $2 \%$ & $75 \%$ & I I $\%$ & $3 \%$ & & \\
\hline
\end{tabular}

TABLE I 3. Overgeneralization errors by verb type and age: Norwegian children

\begin{tabular}{ccccc}
\hline & $\begin{array}{c}\text { Total number } \\
\text { of responses }\end{array}$ & $\begin{array}{c}\text { WL class } \\
\text { Mean (S.D.) }\end{array}$ & $\begin{array}{c}\text { WS class } \\
\text { Mean (S.D.) }\end{array}$ & $\begin{array}{c}\text { S class } \\
\text { Mean (S.D.) }\end{array}$ \\
\hline Age 4 & I680 & $2 \mathrm{I} \%(2 \mathrm{I} \%)$ & $6 \%(\mathrm{I} \mathrm{I} \%)$ & $\mathrm{I} \%(2 \%)$ \\
Age 6 & $\mathrm{I} 740$ & $\mathrm{I} 4 \%(\mathrm{I} \% \%)$ & $8 \%(\mathrm{I} \%)$ & $3 \%(5 \%)$ \\
Age 8 & 2340 & $4 \%(7 \%)$ & $4 \%(8 \%)$ & $\mathrm{I} \%(3 \%)$ \\
\hline
\end{tabular}

T A B LE I 4. Overgeneralization errors by verb type and age: Icelandic children

\begin{tabular}{|c|c|c|c|c|}
\hline & $\begin{array}{l}\text { Total number } \\
\text { of responses }\end{array}$ & $\begin{array}{c}\text { WL class } \\
\text { Mean (S.D.) }\end{array}$ & $\begin{array}{c}\text { WS class } \\
\text { Mean (S.D.) }\end{array}$ & $\begin{array}{c}\text { S class } \\
\text { Mean (S.D.) }\end{array}$ \\
\hline age 4 & I 760 & $39 \%(27 \%)$ & $19 \%($ I $8 \%)$ & $\mathrm{I} \%(2 \%)$ \\
\hline Age 6 & 1650 & $6 \% \quad(7 \%)$ & $14 \%(17 \%)$ & $3 \%(5 \%)$ \\
\hline Age 8 & I650 & $2 \% \quad(4 \%)$ & $8 \%(13 \%)$ & $1 \%(3 \%)$ \\
\hline
\end{tabular}

effect of error type confirms what is already clear from Tables I I, I 2, I 3 and I4, that incorrect responses are not evenly distributed across the error categories. Tukey post hoc analyses indicate that overgeneralization errors (categories I, 2 and 3) are the most prevalent form of error and that overgeneralization to the WL and WS classes are more prevalent than overgeneralization to the $\mathrm{S}$ class. The main effect of age reflects the diminishing number of incorrect responses across error categories with age. 
The main effect of language reflects an overall lower rate of error in the Norwegian children than the Icelandic children. ${ }^{9}$ The error type $\mathrm{x}$ language interaction is driven by the higher proportion of GEN $>$ WS in Icelandic than in Norwegian and higher proportion of GEN $>$ WL errors in Norwegian than Icelandic. The age $\mathrm{x}$ language two-way interaction is driven by the reversal in overall ranking of error rates for Norwegian and Icelandic children between 4 and 6 years of age. Icelandic children are producing fewer errors by age 6 . The two-way interaction of error type with age reflects the diminishing number of GEN $>$ WL errors with age and increasing number of GEN > WS errors with age. The three-way interaction of error type $x$ age $x$ language reflects the slower shift to GEN $>$ WS in Norwegian than in Icelandic. Tukey post hoc analyses showed that GEN $>$ WL errors are significantly different from GEN $>$ WS in both languages at age 6 but in opposite directions.

There are significant developmental differences in the GEN $>$ WL and GEN $>$ WS errors in both languages. In Icelandic, the GEN $>$ WL is the dominant error type at age 4 , significantly higher than GEN $>$ WS (Tukeyb, $p<0.0 \mathrm{I})$. By age 6 , however, it has decreased from $62 \%$ to $22 \%$ of all errors. As the proportion of $\mathrm{GEN}>\mathrm{WL}$ errors decreases, GEN $>\mathrm{WS}$ errors increase, the latter being the dominant error-type at ages 6 and 8 , significantly higher than GEN $>$ WL at ages 6 and 8 (Tukey-b, $p<0.0 \mathrm{I}$ ).

In Norwegian, the developmental profile is similar, but delayed relative to Icelandic. GEN > WL are the main overgeneralization errors at age 4 . These continue to be dominant at age 6, significantly higher than GEN $>$ WS errors at ages 4 and 6 ('Tukey-b test, $p<0.0 \mathrm{I}$ ), but decrease by age 8 . The GEN $>$ WS errors increase slowly from age 4 through 6 , to become the major error type at age 8 in Norwegian as compared to age 6 in Icelandic. The prevalence of GEN $>$ WS over GEN $>$ WL errors is still not statistically significant at age 8 in Norwegian, whereas it is highly significant in Icelandic in age groups 6 and 8 .

Overgeneralization of strong inflections (GEN $>\mathrm{S}$ ) also occur in both languages. They are quite rare at age 4 , but their number increases with age, although not significantly. Within-age-group analyses reveal that in Icelandic GEN $>\mathrm{S}$ is significantly less frequent than both GEN $>\mathrm{WL}$ and GEN $>$ WS at age 4 . By age 6, however, where GEN $>$ WS is the most frequent error (Tukey-b, $p<0.0 \mathrm{I}$ ), the difference between GEN $>\mathrm{S}$ and GEN $>\mathrm{WL}$ errors is no longer significant. In Norwegian, on the other hand, GEN $>\mathrm{S}$

[9] It may seem paradoxical that there is a main effect of language when error rates are used as the dependent measure, but no main effect of language when correct performance is analysed. However, note that only overgeneralization errors are included in this analyses. In particular, the large number of NON-PAST errors produced by the Norwegian fouryear-olds are excluded. 
is significantly less frequent than both types of weak generalizations in all age-groups (Tukey-b, $p<0.05$ at age $4, p<0.0 \mathrm{I}$ at ages 6 and 8 ).

When the development of error-types is compared to the development of correct performance for the two weak classes, it appears that these are synchronized in both languages. In Icelandic (cf. Tables 8, I 2 and I 4 ), the four-year-olds perform best on the WL-class, and they also overgeneralize predominantly into this class. At age 6, the performance on the WS-class makes a spurt. Synchronically, generalization errors into this class make an upwards leap, while the GEN $>$ WL errors decrease substantially. This tendency persists in the eight-year-olds. A similar pattern is observed in Norwegian, only it develops more slowly (cf. Tables 7, II and I3). Interestingly, in a replication of this experiment on adult Norwegian subjects, GEN > WS was found to be the dominant error type, accounting for $45 \%$ of the errors as compared to $10 \%$ of GEN $>\mathrm{WL}$ and $20 \%$ GEN $>$ S (Bjerkan \& Simonsen, r 996; Simonsen \& Bjerkan, r998).

\section{Distribution of error types across verb groups}

Overgeneralizations of both weak inflections are important error types overall, whereas overgeneralizations of strong inflections occur more selectively. GEN > WL errors are relatively evenly distributed across verb groups in both languages, with the exception of the verbs with a monosyllabic infinitive in Norwegian. Seven such verbs were included in the test, three weak and four strong, and they showed virtually no GEN $>$ WL errors. (No such verbs were included for Icelandic, since they are a much less frequent type.) The one -ere verb included in the Norwegian test, reparere 'repair' also exhibited very few GEN $>$ WL errors. GEN $>$ WS errors are found in all the strong classes in both languages, and they also constitute an important source of errors in the WL-class. However, as indicated below, we found some evidence for the role of phonological cues influencing the distribution of these errors.

Although we found no effect of rhyme in the overall correct performance, the distribution of errors, nevertheless, suggests that rhyme plays a role. Overgeneralization of strong inflectional patterns (GEN $>$ S) occur both in weak and strong verbs in both languages. In the weak verbs they are found nearly exclusively in verbs that rhyme with strong ones: for example Norwegian $s y$ 'sew' inflected as søy instead of the correct sydde, in analogy with $f y$ ' $f l y$ ' $\sim f l o y$, and Icelandic hifa 'lift' inflected as heif instead of the correct hifði in analogy with rifa 'tear' $\sim$ reif. Most often they are overgeneralized into strong patterns with a relatively higher type frequency. GEN > S errors are also found in all the strong classes. When strong verbs are overgeneralized according to a strong pattern, either they have some irregularity within their 'own' pattern, (e.g. Norwegian lyve 'tell a lie' 
$l ø y v$ instead of the correct lyve $\sim l \varnothing y)$, or they are inflected in a way similar to another strong pattern, mostly with a higher type frequency (e.g. Norwegian ligge 'lie down' $\sim$ lagg instead of the correct ligge $\sim$ lå). In general, however, the GEN $>\mathrm{S}$ errors are limited in scope, targeting a small range of weak and strong verbs.

Overgeneralizations of the weak inflectional patterns $(\mathrm{GEN}>\mathrm{WL}$ and GEN > WS) to strong verbs are to a large extent predicted by the predominant vowel lengths associated with the two weak classes in Norwegian: the verbs from the subclass SLP, which all have short stem vowels, are overwhelmingly overgeneralized into the WL class, while verbs from subclass SHP, which all have a long stem vowel, as well as those verbs from the SI class which have a long stem vowel, have a more balanced error pattern between GEN > WL and GEN > WS errors, with the WS errors becoming more important with age. In contrast, strong verbs which share vowels with the WL class in Icelandic (see linguistic description p. $2 \mathrm{I}$ ) tend to be overgeneralized to this class only at age 4 when GEN $>$ WL predominates. By age 6, when GEN > WS takes over as the dominating error type, those verbs tend to be overgeneralized to the WS class - so the error patterns predicted by the vowel quality for Icelandic are not supported in the child data. Other phonological patterns which have not yet been identified may be more important. Furthermore, in Icelandic GEN $>$ WS errors often occur on rhyming verbs: in many cases, irregularities within the WS class are evened out. For example, senda 'send' is given the form / sentI/ instead of the correct /sendI/ in accordance with several other verbs rhyming with senda which take the $-t i$ ending, e.g. henda, benda, lenda.

As for non-generalization errors, the few NO-CHANGE errors observed are most frequent within the SHP class both in Norwegian and in Icelandic. The NON-PAST errors, which occur at a high rate at age 4 in Norwegian but then disappear, are found in all verb groups. The few cases of NO ANSWER errors occur mainly in the strong verbs.

\section{DISCUSSION}

Our results reveal a similar order in the developmental profile for the acquisition of past tense inflections in Icelandic and Norwegian, but a difference in rate of development. Whereas the progression of correct performance in Norwegian children is relatively even from age four to eight, the Icelandic children lag behind their Norwegian peers at age four, but subsequently make a spurt in development and catch up with the Norwegian children by age six (cf. Table 6). The profile of error types is to a large extent synchronized with the profile of correct performance. In the following, we discuss the role of type and token frequency and phonological factors in the acquisition of past tense morphology. 
The role of input factors

Type frequency. All three major inflectional classes are acquired in an order reflecting their type frequency in the input language: WL $>\mathrm{WS}>\mathrm{S}$. The larger the number of verbs in an inflectional class (type frequency), the earlier it is acquired. Thus, for four-year-olds the larger weak class is the only class generally mastered above the $80 \%$ level, but for eight-year-olds all three verb classes have reached this level of performance. However, there was no effect of type frequency distinguishing levels of correct performance on the subclasses of strong verbs. This suggests that the differences in type frequencies of these strong classes are too small to differentiate between them. It is also possible that the number of verbs in each of the strong subclasses is too small to allow the statistics to pick up an effect of differences in type frequencies.

The overgeneralization errors follow the same pattern as the correct performance; all three verb classes form bases for overgeneralizations, and to a large extent their relative importance as sources of overgeneralization reflects the type frequency of the classes in the languages. Over the course of development, the smaller weak class and even the strong verbs become increasingly important as a source of generalization errors in both languages, while errors of overgeneralizations into the larger weak class diminish.

These are crosslinguistically valid findings. On the other hand, we also find some important cross-linguistic differences. One of these concerns the smaller weak class which is acquired earlier in Icelandic than in Norwegian, and overgeneralizations to the smaller weak class become the dominant error type much earlier in Icelandic than in Norwegian. This crosslinguistic difference is unexplained by type frequency as the smaller weak class has a higher type frequency in Norwegian $(40 \%)$ than in Icelandic $(21 \%)$. On the other hand, the fact that the composition of the smaller weak class is quite different in the two languages could constitute an element of explanation. As mentioned above, a large majority $(80 \%)$ of this class consists of a welldefined subgroup of verbs ending in -ere in Norwegian. These verbs are loan verbs with a very low token frequency, and most of them are infrequent in the language spoken to children. It is possible that the -ere verbs function as a separate class for the children. The rest of the verbs from the smaller weak class in Norwegian constitute only about $8 \%$ of Norwegian verbs.

Phonological factors. There was little evidence for the role of phonological coherence in predicting correct performance on the strong verb classes in Icelandic and Norwegian. The high coherence class (SHP) was not acquired earlier than the other two strong classes in either Icelandic or Norwegian. However, phonological factors seemed to have an effect on the overgeneralization errors: The phonologically more coherent strong subclasses 
(cf. Tables 2 and 3 ) served as the most important bases of overgeneralization among the strong verbs. Furthermore, almost all GEN $>\mathrm{S}$ errors of weak verbs were restricted to those that rhyme with a strong verb. In Icelandic, rhyming effects were also observed in the smaller weak class. In Norwegian, the predominant vowel lengths of the two weak classes influenced the pattern of overgeneralization of the strong verbs.

Phonological factors may facilitate suffix segmentation in the larger weak class in both languages. Suffixes in this class seem to be more salient than the suffixes in the smaller weak class. In both languages, the larger weak class suffixes begin with a vowel-probably making it easier to recognize or separate from the stem than a suffix beginning with a consonant as is the case for smaller weak verbs, where in many cases assimilations between stem and suffix also make segmentation harder. Furthermore, there is only one suffix in the larger weak class, whereas the smaller weak class has several suffixes to choose between (three in Icelandic, two in Norwegian). In Icelandic, the 'vowel' suffix of the larger weak class is particularly salient, having two syllables as opposed to one in the 'consonant' suffixes of the smaller weak class. In this manner, type frequency and phonological factors can work together to make the larger weak class the easiest one for the children to acquire. The same interaction seems to be at work for the strong verbs - they have both the lowest type frequency and the least segmentable inflection process, making them harder to acquire than the weak verbs.

The smaller weak class gains ground in the course of development both in Icelandic and in Norwegian. Whereas the larger weak class assumes the role of the 'open' class in Norwegian, including verbs of a wide range of phonological patterns, the smaller weak class is less open. In both Icelandic and Norwegian, verbs with monosyllabic infinitives which are not strong, belong to the smaller weak class, and in Norwegian verbs ending in -ere belong there too. For the remaining verbs, the subtle phonological restrictions governing the stems of the weak verbs may influence the pattern of acquisition for the smaller weak class. Subtle tendencies of this kind are probably harder for the children to detect than more clearcut ones, and need a longer time (and more verbs) for them to discover and generalize from. The potential role of these patterns in the acquisition process needs further investigation.

To explain the crosslinguistic differences in the rate of acquisition of the smaller weak class, certain language-specific phonological features may be relevant. In Icelandic, the present tense suffixes are different in the two weak classes. Whereas the infinitive ends in an /a/ in all verb classes, and this /a/ is maintained in the larger weak class in the suffixes for the $\mathrm{Ist}$, 2nd and $3 \mathrm{rd}$ p.sg. both in the present and the past tense, the corresponding suffixes in the smaller weak class contain an /I/ (cf. Table I). For the Icelandic child, the vowel patterning in the present tense may thus function as a cue to class 
membership of the weak verbs and help distinguish verbs from the smaller weak class from that of the larger weak class. In Norwegian, on the other hand, (at least in the dialect of Norwegian we are investigating), present tense does not differ between the two weak classes, and does not provide the children with such a cue.

Token frequency. An overall effect of token frequency of verbs was found in both languages and all age groups. The past tense forms of more frequent verbs were acquired more easily than those of less frequent verbs. The effects of token frequency interact with verb classes in both languages, but in different ways. In Icelandic, the difference between performances on high and low token frequency verbs was significant for all three classes of verbs and in all age groups. The difference was greatest in the larger weak class, and smallest in the strong verbs. The pattern of results could reflect the fact that in choosing strong verbs for the elicitation test, we were careful not to choose verbs that the child might not have heard, whereas in the weak verbs there were three to four verbs which are so infrequent that the children may not have heard them before. These were included because they rhymed with strong verbs.

In Norwegian, significant contrasts for token frequency appeared in the strong verbs and the verbs from the larger weak class, but not within the smaller weak class. We have no explanation for the lack of a token frequency effect in the WS class. However, token frequency may help explain the low performance on SHP verbs: in both languages the token frequency of the verbs in this class is generally lower than that of other strong verbs, and this is reflected in the verbs chosen for the test.

It is clear that token frequency is a significant factor in explaining the correct performances not only of the strong verbs, but also that of the most frequent pattern, i.e. the larger weak classes, for both languages.

\section{CONCLUSIONS}

Our results indicate that the role of morphological complexity is most important at the earliest stages of development. At the age of four, the Icelandic children show a lower level of performance than their Norwegian peers, in particular on the strong verbs, but this difference has evened out already at the age of six. This crosslinguistic difference may be linked to the greater morphological complexity of the Icelandic inflectional system.

But more importantly, our results provide further support for the claim that type frequency, token frequency and phonological sub-regularities play an important role in the acquisition of inflectional morphology. Type frequency is most clearly manifested in order of acquisition effects. Icelandic and Norwegian children show higher levels of correct performance on verbs 
with high type frequency at an earlier age than verbs with a low type frequency. However, type frequency also has an impact on the productivity of the inflectional types. All verb types (larger weak, smaller weak and strong) were a source of overgeneralization errors but the overall number of each error type was predicted by the type frequency of the inflectional class (more GEN $>$ WL than GEN > WS, and more GEN $>$ WS than GEN $>$ S). An unexpected finding was that the smaller weak class became the largest source of errors (Norwegian) or the predominant source of errors (Icelandic) in the older age groups. This result indicates that type frequency is not exclusive in determining the productivity of a given inflectional type.

From the perspective of generative, symbolic accounts of inflectional morphology, one interpretation of these findings is that the smaller weak class functions as the minority default rule in Icelandic and Norwegian. This interpretation is lent further support by the finding that there is no evidence of token frequency effects in the smaller weak class in Norwegian. Furthermore, we have not been able to identify any consistent phonological cues that determine overgeneralization into the smaller weak class in Icelandic. These are hallmarks of a default inflectional rule in operation (Pinker, I 99 I). However, several other findings guard against this interpretation of our results. First, the smaller weak class in Icelandic exhibits reliable token frequency effects. Furthermore, we have not been able to identify any consistent phonological cues that determine overgeneralization into the larger weak class in Icelandic. Secondly, overgeneralization into the smaller weak class in Norwegian appears to be strongly influenced by phonological factors. For example, verbs with a monosyllabic infinitive exclusively overgeeneralize into the smaller weak class, and vowel length in strong verbs is a good predictor of error type (strong verbs with short vowels tend to be overgeneralized according to the larger weak pattern while strong verbs with long vowels show a more balanced overgeneralization pattern corresponding to the vowel quantity patterns of the larger weak and smaller weak classes).

Taken together with the findings that the larger weak class exhibits token frequency effects in both Icelandic and Norwegian, we conclude that there is little evidence in support of the claim that either of the weak inflectional classes act as an inflectional default in Icelandic or Norwegian.

From the perspective of exemplar-based accounts of inflectional morphology, the findings that type and token frequency, and phonological subregularities impact on patterns of acquisition and productivity comes as no surprise. Productivity of inflectional classes should be graded according to their type frequency; accuracy and age of acquisition of individual verbs should correlate with their token frequency; and error patterns should be influenced by the phonological sub-regularities defining the different inflectional types, and should also reflect the differences in correct performance on the different verb types at different ages. By and large, all these 
predictions are confirmed by the findings reported here. However, there are several findings which remain unexplained by exemplar-based approaches. First, we found no effect of token frequency for the smaller weak class in Norwegian. We have no explanation for this finding, especially given the consistency of token frequency effects for all other verb classes in Icelandic and Norwegian. Secondly, we have been unable to identify any consistent phonological cues that predict overgeneralization errors into either of the weak classes in Icelandic. Given the relative lack of detailed linguistic description for the Icelandic verb classes (as compared to say Norwegian), the failure to identify consistent phonological cues (and so predict errors) may reflect our impoverished state of knowledge with respect to the phonological patterns underlying verb class membership in Icelandic. In any case, further linguistic investigation is needed here.

Perhaps the most intriguing finding to emerge from our experiments is that the predominant source of overgeneralization errors shifts during the course of development from the larger weak class to the smaller weak class. Recall that a similar pattern of development has been reported for the acquisition of the Arabic plural system (Ravid \& Farah, I997), where the 'sound plural' was replaced by the 'broken plural' as the primary source of error in the older children study. Note that this pattern of development was predicted by an exemplar-based model of the Arabic plural system (Plunkett \& Nakisa, 1997). On that account, the larger type frequency of the Arabic 'sound plural' forced early overgeneralization of the 'sound plural' pattern, while the incremental learning of the 'broken plural' system together with its broader phonological distribution resulted in its later dominance as a source of error. To what extent can we explain the corresponding shift in Icelandic and Norwegian children?

Clearly, the type frequency of the larger weak class readily explains the predominance of overgeneralization errors to this class in the Icelandic and Norwegian four-year-olds. Our results indicate that verbs from this class dominate four-year-olds' knowledge of past tense inflection, and it is the pattern underlying this class (the vowel suffix) which is the primary source of productivity. As the older children accumulate more knowledge about the smaller weak class, this becomes a source of productivity and overgeneralization errors. But why does the smaller weak class come to dominate the larger weak class in this respect? One possibility is that the smaller weak class has a wider phonological distribution than the larger weak class, and therefore is a better candidate for producing widespread interference effects. However, we have no evidence that this is the case in Icelandic and evidence to the contrary for Norwegian. For example, Norwegian sets restrictions on consonantal endings in the smaller weak class but not the larger weak class. A second possibility is that the particular set of verbs we selected for our experiment happened to show greater similarity to the smaller weak class 
than is the case for the language as a whole. This would explain why the older children are more likely to show overgeneralizations to the smaller weak class; as they learn more about the smaller weak class, the chances of the experimental verbs exhibiting similarity effects to the smaller weak class are enhanced. However, in selecting our experimental stimuli, we deliberately attempted to choose a representative sample from the two languages. We conclude, therefore, that the shift to the smaller weak type of overgeneralization error is unlikely to be an artefact of the testing material we used.

A final possibility relates to the greater segmentability and saliency of the suffix in the larger weak class relative to the smaller weak class (see linguistic description), making the larger weak class easier to learn and to generalise than the smaller weak class. On the other hand, verbs from the smaller weak class are more commonly used (i.e. have a higher token frequency) in both languages. ${ }^{10}$ An interaction between these two factors may lead to the profile of development observed: ease of segmentability leading to early learning and generalization of the larger weak pattern and greater overall prevalence (tokenwise) of the smaller weak pattern leading to more robust long-term learning and increasing levels of generalization. One way to test this multi-factor account of our developmental findings would be to construct an exemplar-based model (à la Plunkett \& Nakisa, I997) to determine whether an interaction between segmentability and token frequency effects produces the observed generalization profile.

\section{REFERENCES}

Berko, J. (1958). The child's learning of English morphology. Word 14, I 50-I 77 .

Bjerkan, K. M. \& Simonsen, H. G. (I 996). Prosessering av preteritumsformer i norsk: Eksperimentell evidens fra barn og voksne. Norsk Lingvistisk Tidsskrift 14, I89-207.

Bokmålsordboka. ( I 986). Oslo: Universitetsforlaget.

Bybee, J. L. (1985). Morphology. Philadelphia: Johns Benjamins.

Bybee, J. L. (1995). Regular morphology and the lexicon. Language and Cognitive Processes Io, $425^{-55}$.

Bybee, J. L. \& Slobin, D. I. (1982). Rules and schemas in the development and use of English past tense. Language $\mathbf{5}^{8}, 265^{-89}$.

Clahsen, H., Rothweiler, M., Woest, A. \& Marcus, G. S. (1992). Regular and irregular inflection in the acquisition of German noun plurals. Cognition 45, 225-55.

Ervin, S. \& Miller, W. R. (1963). Language development. In H. W. Stevenson (ed.), Child psychology: the sixty-second yearbook of the National Society for the Study of Education, Part I. Chicago: University of Chicago Press.

[I0] Only $7 \%$ of the past tense and past participle tokens occurring in the input to the Icelandic boy, Ari, in approximately 60 hours of recorded speech in his home beteween ages 2 and 6 were PT or past participles of verbs from the WL class, as compared to $22 \%$ from the WS class and $7 \mathrm{I} \%$ were strong verbs. The distribution of the child's use of PT closely mirrored these proportions (Ragnarsdóttir, I 997). 
Gíslason, J. (1992). Veikar sagnir í íslensku. Paper presented at Háskóli Íslands.

Hagen, J. E. ( I 994). Svake verb på -Vde og -Vte i bokmål og deres paradigmetilhørighet. J. Myking, H. Sandøy \& I. Utne (eds), Helsing til Lars Vassenden på 70-årsdagen. Bergen: Nordisk institutt.

Hare, M., Elman, J. L. \& Daugherty, K. G. (1995). Default generalisation in connectionist networks. Language and Cognitive Processes 10, $60 \mathrm{I}-30$.

Heggstad, K. (1982). Norsk frekvensordbok. Oslo: Universitetsforlaget.

Kuczaj, S. A. (1977). The acquisition of regular and irregular past tense forms. Fournal of Verbal Learning and Verbal Behavior 16, 589-600.

Langacker, R. W. (1987). Foundations of cognitive grammar. Vol. I: Theoretical prerequisites. Stanford: Stanford University Press.

Langacker, R. W. ( 1 988). A usage based model. In B. Rudzka-Ostyn (ed.), Topics in Cognitive linguistics. Amsterdam: Benjamins.

MacWhinney, B. \& Leinbach, J. (I99I). Implementations are not conceptualizations: Revising the verb learning model, Cognition 39, I 2 I-57.

Magnússon, F. \& Briem, S. ( I 99I). Íslensk orðtıðnibók. Jörgen Pind (ed.), Reykjavík: Orðabók Háskólans.

Marchman, V. A. (1997). Children's productivity in the English past tense: the role of frequency, phonology and neighborhood structure. Cognitive Science 21, 283-304.

Marcus, G. F. (1995). Children's overregularizations of English plurals: a quantitative analysis. Fournal of Child Language 22, 447-59.

Marcus, G. F., Pinker, S., Ullman, M., Hollander, M., Rosen, T. J. \& Xu, F. (1992). Overregularization in language acquisition. Monographs of the Society for Research in Child Development $\mathbf{5 7}$ (4).

Marcus, G. F., Brinkmann, U., Clahsen, H., Wiese, R. \& Pinker, S. (I995). German inflection: the exception that proves the rule. Cognitive Psychology 29, I89-256.

Nakisa, R. C. \& Hahn, U. ( ( 996). Where defaults don't help: the case of the German plural system. In G. W. Cottrell (ed.), Proceedings of the Eighteenth Annual Conference of the Cognitive Science Society. Mahwah, NJ : Erlbaum.

Orsolini, M., Fanari, R. \& Bowles, H. (I 998). Acquiring regular and irregular inflection in a language with verb classes. Language and Cognitive Processes 13, 425-64.

Pinker, S. \& Prince, A. (1988). On language and connectionism: analysis of a parallel distributed processing model of language acquisition. Cognition 28, 73-193.

Pinker, S. (I 991). Rules of language. Science $\mathbf{2 5 3}$, 530-5. $^{2}$

Pizzuto, E. \& Caselli, M. C. (I992). The acquisition of Italian morphology: implications for models of language development. Fournal of Child Language 19, 49 I-557.

Plunkett, K. \& Marchman, V. (I99I). U-shaped learning and frequency effects in a multilayered perceptron: implications for child language acquisition. Cognition 38, 43-102.

Plunkett, K. \& Marchman, V. ( 1993 ). From rote learning to system building. Acquiring verb morphology in children and connectionist nets. Cognition 48, 2 I-69.

Plunkett, K. \& Marchman, V. (1996). Learning from a connectionist model of the English past tense. Cognition 6r, 299-308.

Plunkett, K. \& Nakisa, R. C. (I997). A connectionist model of the Arabic plural system. Language and Cognitive Processes 12, 807-38.

Plunkett, K. \& Juola, P. (in press). A connectionist model of English past tense and plural morphology. Cognitive Science.

Prasada, S., Pinker, S. \& Snyder, W. (I990). Some evidence that irregular forms are retrieved from memory but regular forms are rule generated. Paper presented at the 3 Ist annual meeting of the Psychoniomic Society, New Orleans.

Prasada, S. \& Pinker, S. (I 993). Generalisation of regular and irregular morphological patterns. Language and Cognitive Processes 8, I-56.

Ragnarsdóttir, H. (I 997). The role of input in Icelandic children's acquisition of past tense morphology. Experimental and longitudinal evidence. Paper presented at Cognitive Models of Language Acquisition, Odense Universitet, Odense.

Ravid, D. \& Farah, R. ( 1 997). Learning about noun plurals in early Palestinian Arabic. Paper presented at $G A L A$, Edinburgh. 
Rumelhart, D. E. \& McClelland, J. L. (i 986). On learning the past tenses of English verbs. In J. L. McClelland, D. E. Rumelhart \& the PDP research group (eds), Parallel distributed processes: explorations in the microstructure of cognition. Volume 2: Psychological and biological models. Cambridge, MA: Bradford Books/MIT Press.

Seidenberg, D. L. \& Bruck, M. (r990). Consistency effects in the generation of past tense morphology. Paper presented at the 3 Ist meeting of the Psychoniomic Society, New Orleans.

Simonsen, H. G. \& Bjerkan, K. M. (r 998). Testing past tense inflection in Norwegian: a diagnostic tool for identifying SLI children? International Fournal of Applied linguistics 8-2, $25 \mathrm{I}-70$.

TAUS (Talemålsundersøkelsen i Oslo). (ı 978). Main report: E. Hanssen, T. Hoel, E. H. Jahr, O. Rekdal, G. Wiggen: Oslomål. Oslo: Novus.

Xu, F. \& Pinker, S. (I995). Weird past tense forms. Fournal of Child Language 22, $53 \mathrm{I}^{-} 56$.

\section{APPENDIX I}

EXAMPLES OF HOW THE ELICITATION TASK WAS FORMULATED IN

THE TWO LANGUAGES

Norwegian

'Her ser du en gutt ligge/som ligger i sengen. Han gjorde akkurat det samme i går. Hva gjorde han da?'

'Han'

Icelandic

'Hér sérðu strák liggja i rúminu sínu. Hann gerði pað sama i gar. Hvað gerð $i$ hann i ger? Hann'

\section{English translation}

'Here you see a boy lie/who lies in the bed. he did exactly the same yesterday. What did he do then? He'

\section{APPENDIX 2}

LIST OF VERBS INCLUDED IN THE TEST

Each verb is presented with the infinitive form in capital letters, followed by an English translation in parenthesis. The subsequent forms are the simple past tense and the past participle.

NORWEGIAN

Strong verbs

(27 verbs)

I. SLP (Strong, low phonological coherence) $(n=9)$

SITTE (sit) satt sittet 
DRIKKE (drink) drakk drukket

STIKKE (sting) stakk stukket

HJELPE (help) hjalp hjulpet

SYNGE (sing) sang sunget

DETTE (fall) datt dettet

SPREKKE (burst) sprakk sprukket

SPINNE (spin) spant spunnet

FINNE (find) fant funnet

2. SHP (Strong, high phonological coherence) $(n=9)$

FLY (fly) fløy fløyet

BRYTE (break) brøt brutt

FRYSE (freeze, be cold) frøs frosset

STRYKE (iron, stroke, flunk) strøk strøket

SKYTE (shoot) skjøt skutt

LYVE (tell a lie) løy løyet

FLYTE (float) fløt flytt

FYKE (blow, drift) føk føket

KLYPE (pinch) kløp kløpet

3. SI (Strong, idiosyncratic) $(n=9)$

HETE (be called) het hett

HOLDE (hold) holdt holdt

LØPE (run) løp løpt

SOVE (sleep) sov sovet

GRAंTE (weep) gråt grått

STA (stand) sto stått

LIGGE (lie) lå ligget

GI (give) ga gitt

LE (laugh) lo ledd

Larger weak class

( 6 verbs)

4. WLR (Larger weak class; verbs rhyming with strong) $(n=8)$

TITTE (peep) tittet tittet

VEKKE (wake up) vekket vekket

FLETTE (plait) flettet flettet

NIKKE (nod) nikket nikket

SLIKKE (lick) slikket slikket

GYNGE (swing) gynget gynget

FOLDE (fold) foldet foldet

LOVE (promise) lovet lovet

5. WLN (Larger weak class; verbs not rhyming with strong) $(n=8)$

KASTE (throw) kastet kastet 
HOPPE (jump) hoppet hoppet

BADE (bathe) badet badet

PLUKKE (pick) plukket plukket

SPARKE (kick) sparket sparket

KYSSE (kiss) kysset kysset

ROTE (untidy) rotet rotet

DUSJE (shower) dusjet dusjet

\section{Smaller weak class}

( 7 verbs)

6. WSR (Smaller weak class; verbs rhyming with strong) $(n=8)$

SPISE (eat) spiste spist

RINGE (ring, call) ringte ringt

LYSE (light) lyste lyst

SKINNE (shine) skinte skint

SPÅ (foretell) spådde spådd

GRE (comb) gredde gredd

KJØPE (buy) kjøpte kjøpt

SY (sew) sydde sydd

7. WSN (Smaller weak class; verbs not rhyming with strong) $(n=9)$

TENKE (think) tenkte tenkt

LEKE (play) lekte lekt

KJØRE (drive) kjørte kjørt

SPILLE (play) spilte spilt

SMAKE (taste) smakte smakt

MALE (paint) malte malt

SVØMME (swim) svømte svømt

BAKE (bake) bakte bakt

REPARERE (repair) reparerte reparert

I C E L A N D I C

Strong $(S)$

(30 verbs)

I. SLP (Strong, low phonological coherence) $(n=9)$

BINDA (tie) batt bundum bundið

DETTA (fall) datt duttum dottið

DREKKA (drink) drakk drukkum drukkið

FINNA (find) fann fundum fundið

HVERFA (vanish) hvarf hurfum horfið

SPINNA (spin) spann spunnum spunnið 
SPRINGA (burst) sprakk sprungum sprungið

STINGA (sting) stakk stungum stungið

VINNA (work) vann unnum unnið

2. SHP (Strong, high phonological coherence) $(n=9)$

BJÓĐA (invite) bauð buðum boðið

BRJÓTA (break) braut brutum brotið

FJÚKA (blow away) fauk fukum fokið

FLJÚGA (fly) flaug flugum flogið

HRJÓTA (snore) hraut hrutum hrotið

LJÚGA (lie) laug lugum logið

SJÓĐA (boil) sauð suðum soðið

SKJÓTA (shoot) skaut skutum skotið

SÚPA (drink) saup supum sopið

3. SI (Strong, ideosyncratic) $(n=\mathrm{I} 2)$

DEYJA (die) dó dóum dáið

HALDA (hold/think) hélt héldum haldið

HLAUPA (run) hljóp hlupum hlaupið

HLÆJA (laugh) hló hlógum hlegið

HRÖKKVA (startle) hrökk hrukkum hrokkið

LEIKA (play) lék lékum leikið

LIGGJA (lie) lá lágum legið

SITJA (sit) sat sátum setið

SOFA (sleep) svaf sváfum sofið

STANDA (stand) stóð stóðum staðið

STÖKKVA (jump) stökk stukkum stokkið

SYNGJA (sing) söng sungum sungið

Larger weak class $(W L)$

( 13 verbs)

4. WLR (Larger weak class; verbs rhyming with strong) $(n=8)$

BAKA (bake) bakaði bakað

HLJÓĐA (scream) hljóðaði hljóðað

HRINGA (round up) hringaði hringað

LOFA (promise) lofaði lofað

MYNDA (make) myndaði myndað

SAGA (saw) sagaði sagað

STJÓRNA (govern) stjórnaði stjórnað

STÚTA (brake) stútaði stútað

5. WLN (Larger weak class; verbs not rhyming with strong) $(n=5)$

HJÁLPA (help) hjálpaði hjálpað

KASTA (throw) kastaði kastað

SMAKKA (taste) smakkaði smakkað

6 I 7 
SPARKA (kick) sparkaði sparkað

SPILA (play) spilaði spilað

Smaller weak class

( 12 verbs)

6. WSR (Smaller weak class; verbs rhyming with strong) $(n=8)$

FLÝTA (hurry) flýtti flýtt

GRETTA (make a face) gretti grett

HÍFA (lift) hífði híft

HRINGJA (ring, call) hringdi hringt

HVÍLA (rest) hvíldi hvílt

KENNA (teach) kenndi kennt

SYNDA (swim) synti synt

ÝTA (push) ýtti ýtt

7. WSN (Smaller weak class; verbs not rhyming with strong) $(n=4)$

BENDA (point at) benti bent

KEYRA (drive) keyrði keyrt

KYSSA (kiss) kyssti kysst

SENDA (send) sendi sent 